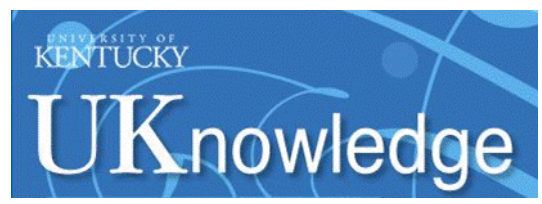

Kentucky Journal of Equine, Agriculture, \& Natural Resources Law

\title{
Energy, Electricity and Smart Grids in Latvia and Portugal - Developments and Concerns
}

\author{
Rafael Leal-Arcas \\ Queen Mary University of London \\ Filipa Santos \\ Queen Mary University of London \\ Danai Papadea \\ Queen Mary University of London
}

Follow this and additional works at: https://uknowledge.uky.edu/kjeanrl

Part of the Comparative and Foreign Law Commons, Energy and Utilities Law Commons, and the Environmental Law Commons

Right click to open a feedback form in a new tab to let us know how this document benefits you.

\section{Recommended Citation}

Leal-Arcas, Rafael; Santos, Filipa; and Papadea, Danai (2020) "Energy, Electricity and Smart Grids in Latvia and Portugal - Developments and Concerns," Kentucky Journal of Equine, Agriculture, \& Natural Resources Law: Vol. 12: Iss. 3, Article 2.

Available at: https://uknowledge.uky.edu/kjeanrl/vol12/iss3/2

This Article is brought to you for free and open access by the Law Journals at UKnowledge. It has been accepted for inclusion in Kentucky Journal of Equine, Agriculture, \& Natural Resources Law by an authorized editor of UKnowledge. For more information, please contact UKnowledge@lsv.uky.edu. 


\title{
Energy, Electricity and Smart Grids in Latvia and Portugal - Developments and Concerns
}

\author{
Rafael Leal-Arcas, ${ }^{\star}$ Filipa Santos,` Danai Papadea*
}

\begin{abstract}
This article explores the electricity sector of Latvia and Portugal, the European Union's (EU) policy on clean energy, electricity, and smart technologies, the relationship developed between them, and the feasibility of smart grids' and other new tools and technologies' popularisation in the context of the Latvian and Portuguese electricity markets. As member states of the EU, Latvia and Portugal must follow the decentralization agenda while increasing their use of encouraging renewable energy sources and establish better interconnection of electricity between their respective neighbouring member states. In this context, this article explores the electricity market of Latvia and Portugal, taking into account promising policies introduced by the EU that aim to incorporate new technologies such as storage solutions and the creation of smart grids.

The article looks at how the priority of decentralized energy is being achieved in Latvia and Portugal. It explores the current domestic energy market in both countries, the current remarkable achievements in energy decentralization in terms of policy and legislation, as well as unique obstacles that have become apparent. It assesses new technologies and novel projects introduced to incentivize or further develop such technologies,
\end{abstract}

\footnotetext{
* Jean Monnet Chaired Professor in EU International Economic Law and Professor of Law, Queen Mary University of London (Centre for Commercial Law Studies), United Kingdom. Visiting Researcher, Yale Law School. Visiting Professor, New York University Abu Dhabi. Inaugural Lee Kong Chian International Visiting Professor, Singapore Management University School of Law, Singapore. Member, Madrid Bar. Ph.D., European University Institute; M.Res., European University Institute; J.S.M., Stanford Law School; LL.M., Columbia Law School; M.Phil., London School of Economics and Political Science; J.D., Granada University; B.A., Granada University. The financial help from two European Union (EU) grants is gratefully acknowledged: Jean Monnet Chair in EU International Economic Law (project number 575061-EPP-1-2016-1-UK-EPPJMOCHAIR) and the WiseGRID project (number 731205), funded by the EU's Horizon 2020 research and innovation program. Email: r.leal-arcas@qmul.ac.uk

- Research Associate, Queen Mary University of London, WiseGRID project. Email: filipadssantos94@gmail.com

- Research Associate, Queen Mary University of London, WiseGRID project. Email:danaepap27@gmail.com
} 
namely smart metering systems, electric mobility, demand response, and electricity storage technologies. The article also looks at data protection concerns, the interconnection between the electricity markets of Portugal and Spain and the possibility of a place in the market for the new clean energy sources. The article concludes the domestic reality in both countries and outlines a set of recommendations to facilitate the introduction of new technologies in the energy sector and how to further implement the decentralization of the electricity market.

\section{INTRODUCTION}

Pursuant to its commitments under the landmark Paris Agreement on Climate Change, the European Union (EU) has proved itself to be a leader in the fight against climate change. ${ }^{1}$ This is supported by the fact that the EU was the first major economy to establish a legally binding framework for its Member States in order to fulfil those climate change commitments, and is currently progressing toward the goal of achieving climate neutrality by 2050 through reducing its carbon emissions. ${ }^{2}$ Preparing for its long-term goal, the EU needs to present a strategy to achieve it by $2020 .^{3}$ There are many foreseeable challenges for the future, including the transition to the circular economy, the effective implementation of smart grids, the energy transition, smart cities, making use of electricity to reduce maternal mortality, the transportation revolution, and the way in which technology, innovation and sustainability will transform the way we live, inter alia.

One of the ways to promote electricity derived from lowcarbon, renewable energy is the development of smart electricity grids or "smart grids." 4 Smart grids are described as a network

\footnotetext{
${ }^{1}$ Sebastian Oberthür, Perspectives on EU Implementation of the Paris Outcome, 10 Carbon \& Climate L. Rev., 34, 34-45, (2016).

2 European Commission, Energy Union: Commission calls on Member States to step up ambition in plans to implement Paris agreement, PRess Release, BRUssels (June 18, 2019), https://ec.europa.eu/commission/presscorner/detail/en/IP_19_2993 [https://perma.cc/27GQ-YV5Z].

3 EUROPEAN COMMISSION, The European Union continues to lead the global fight against climate change (Sept. 11, 2019), https://europa.eu/rapid/press-release_IP-195534_en.htm [https://perma.cc/SA7E-JLXQ].

4 European Commission, Communication from the Commission to the European Parliament, the Council, the European Economic and Social Committee and the Committee of the Regions, Smart Grids: from innovation to deployment (April 11, 2011).
} 
"that can [cost] efficiently integrate the behaviour and actions of all users connected to it - generators, consumers and those that do both". 5 They are able to safely integrate not only renewable energy in a country's energy mix, but also electric vehicles and distributed generators in its network. ${ }^{6}$ Smart grids are deemed more reliable and capable to prevent or restore power outages thanks to their self-healing via automatic grid reconfiguration. ${ }^{7}$ Furthermore, the promotion of smart grids has the potential to provide, amongst others, energy security in the markets in which it is implemented. ${ }^{8}$ Smart grids constitute a unique opportunity for citizen empowerment ${ }^{9}$ through decentralization, conversely with the traditional centralised structure of energy networks. ${ }^{10}$

This article explores the electricity sector of Latvia and Portugal, the European Union's policy on clean energy, electricity, and smart technologies, the relationship developed between them, and the feasibility of smart grids' and other new tools and technologies' popularisation in the context of the Latvian and Portuguese electricity markets.

The EU has been the most active region in the world in evolving energy policy and implementing climate change and

\footnotetext{
${ }^{5} I d$.

${ }^{6}$ Vincenzo Giordano, et al., Smart Grid projects in Europe: Lessons learned and current developments, JoINT RESEARCH CENTRE SCIENTIFIC AND POLICY REPORTS, Report EUR 25815 EN (2013),

https://ses.jrc.ec.europa.eu/sites/ses.jrc.ec.europa.eu/files/documents/ld-na-25815-en-

n_final_online_version_april_15_smart_grid_projects_in_europe_lessons_learned_and_cu rrent_developments_-2012_update.pdf, p. 3. [https://perma.cc/KQ8X-QCC3].

${ }^{7} I d$.

${ }^{8}$ R. Leal-Arcas, M. Greger, and H. Knigge, Towards energy democratization, 31 Colorado NAt. Resources, EnERGy, And EnVtL L. ReV., 101-185 (2020); R. Leal-Arcas, F. Leniewska, and F. Proedrou, Smart grids in the European Union: Assessing energy security, regulation \& social and ethical considerations, 24.2 COLUM. J. OF EUR. L., 291389 (2018); R. Leal-Arcas, Empowering citizens for common concerns: Sustainable energy, trade and climate change, 6 GSTF J. OF L. AND Soc. SCI., 1-37 (Jan. 2018); R. Leal-Arcas, M. Peykova, V. Nalule, and P. Kara, Decarbonizing the energy sector, XV J. OF ANIMAL AND NAT. RESOURCE L., 173-271 (2019).

${ }^{9} I d$.

${ }^{10}$ Vincenzo Giordano, et al., Smart Grid projects in Europe: Lessons learned and current developments - 2012 update, EUR. COMM'n, JOINT RES. CENTRE SCI. \& POL'Y REP., Report EUR 25815 EN, (2013),

https://ses.jrc.ec.europa.eu/sites/ses.jrc.ec.europa.eu/files/documents/ld-na-25815-en-

n_final_online_version_april_15_smart_grid_projects_in_europe_lessons_learned_and_cu rrent_developments_-2012_update.pdf [https://perma.cc/4NGR-ZHBE]; Rafael Leal-Arcas, Feja Lesniewska, Filippos Proedrou, Prosumers as New Energy Actors, AfricA-EU RENEWABLE ENERGY RES. \& INNOVATION SYMP. (RERIS 2018),

https://link.springer.com/chapter/10.1007/978-3-319-93438-9_12 [https://perma.cc/524JHH4Z] (last viewed Oct. 16, 2020).
} 
environmental standards. ${ }^{11}$ This has led to the successful reduction of pollution, while growing the economy and fostering global technological leadership. ${ }^{12}$ However, EU member states still import a high level of fossil fuels such as oil and gas to produce electricity in their domestic energy systems, and Latvia and Portugal are no exception. ${ }^{13}$ The high imports and usage of fossil fuels pose a threat to the EU's decarbonization path and are contrary to a sustainable development. ${ }^{14}$

The decentralization and diversification of energy sources are a priority in the EU's agenda. ${ }^{15}$ This is not only for environmental reasons, but also due to the still oligopolistic nature of the production, consumption, and trade of oil and gas, and the unreliability of their supply due to geopolitical instability in oil-rich countries, ${ }^{16}$ the volatility of oil prices and nationalism of resources, amongst other reasons. ${ }^{17}$ To continue with fossil fuel

${ }_{11}$ Alina Averchenkova, et al., Climate policy in China, the European Union and the United States: main drivers and prospects for the future - in depth country analyses, Pol'y Paper, Centre for Climate Change Econ. and Pol'y Grantham Res. Inst. ON Climate Change \& the Env'T in Collaboration with BRuegel \& Scholars at the Centre on Global Energy Pol'y at Colum. University's Sch. OF InT'L and Public AFFAIRS, 1-96, at 36 (2016).

12 Ger Klaassen et al., EU climate policy explained, 1, 4 RoUTLEDGE Publishing, (1st ed. 2015).

https://ec.europa.eu/clima/sites/clima/files/eu_climate_policy_explained_en.pdf [https://perma.cc/LKW9-GXUY].

13 See generally R. Leal-Arcas, Solutions for Sustainability: How the International Trade, Energy, and Climate Change Regimes Can Help, SPRINGER InTERnAtional PUBLISHING (2019); R. Leal-Arcas, Re-thinking global climate change: A local, bottom-up perspective, SETON HALl J. OF DiPlomaCY AND INT'L RELATIONS, Vol. XX, No. 1, 4-20, 2018; R. Leal-Arcas and A. Morelli, The Resilience of the Paris Agreement: Negotiating and Implementing the Climate Regime, 31.1 GEO. EnVt'L L. REV., 1-63 (2018); R. Leal-Arcas, New Frontiers of International Economic Law: The quest for sustainable development, 40 U. of PEnnsylvania J. OF INT'L L., Issue 1, 83-132, 2018; R. Leal-Arcas, Sustainability, common concern and public goods, 49 THE GEORGE WASHINGTON INt'L L. REV., Issue 4, 801-77 (2017).

${ }^{14} I d$.

15 See generally R. Leal-Arcas and J. Wouters, Research Handbook on EU Energy Law and Policy, Cheltenham: Edward Elgar Publishing Ltd (2017); R. LealArcas et al., Energy security, trade and the EU: regional and international perspectives, Cheltenham: Edward Elgar Pub. LTd (2016); R. Leal-Arcas, The European Energy Union: The Quest for Secure, Affordable and Sustainable Energy, ClaEYs \& CASTEELS PUB. (2016); R. Leal-Arcas, A. Filis and E. Abu Gosh, International Energy Governance: Selected Legal Issues, Cheltenham: EdWARd ElGAR PUB. Ltd, (2014).

${ }^{16}$ R. Leal-Arcas, et al., Energy trade in the MENA Region: Looking beyond the Pan-Arab electricity market, 10 J. OF WorLd ENERGY LAW \& Business, Issue 6, 520-49, Oxford University Press (2017).

17 R. Leal-Arcas, et al., Energy decentralization in the EU, QUEEN MARY U. OF LONDON, Sch. OF L. LEGAL STUD. Res. PAPER No. 307/2019, 1-54, at 2. 
production and imports for the generation of electricity is not a sustainable option for the EU and the world, as it no longer meets energy demands and is irreversibly changing our natural environment. The role of clean energy sources in the energy mix of a country is more crucial than ever before. Fostering innovation can aid in finding solutions to energy security concerns, while, at the same time, can help safeguard sustainable growth and the protection of the environment. ${ }^{18}$

The EU's "Third Energy Package" has promoted a greener energy policy by making member states focus on the decentralization of their domestic electricity markets. ${ }^{19}$ More recently, the introduction of the "clean energy for all Europeans" package has reinforced the EU's position on the crucial role clean energy and energy efficiency have within its internal energy market. ${ }^{20}$ This results in increasing the role consumers have in the electricity market and integrating renewable energy sources into a more technological grid. ${ }^{21}$ Smart grids are expected to increase substantially across Europe. ${ }^{22}$ The decentralization shift from the large centralized power stations to smaller and more distributed local grids will better utilize electricity produced from renewable energy sources and create innovative new technologies to support the low-carbon transition. ${ }^{23}$

As member states of the EU, Latvia and Portugal must follow the decentralization agenda while increasing their use of renewable energy sources and establish better interconnection of electricity between their respective neighbouring member states. In this context, this article explores the electricity market of Latvia and Portugal, taking into account policies introduced by

${ }_{18} \mathrm{R}$. Leal-Arcas et al., The contribution of free trade agreements and bilateral investment treaties to a sustainable future, ZEITSCHRIFT FÜR EUROPARECHTLICHE STUDIEN - ZEUS, (Jan. 1, 2020); R. Leal-Arcas et al., Aiming at sustainable trade in the context of the Rule of Law: What role for citizens and how international trade can help reduce fossil-fuel consumption, 11 TRADE, LAW AND DEVELOPMENT, 2 (2019).

19 See European Union Commission, Third energy package (May 21, 2019), https://ec.europa.eu/energy/en/topics/markets-and-consumers/market-legislation/thirdenergy-package [https://perma.cc/5Z36-DJFT].

${ }^{20}$ European Commission, Clean energy for all Europeans package completed: good for consumers, good for growth and jobs, and good for the planet, Press Release, Brussels (May 27, 2019), https://ec.europa.eu/info/news/clean-energy-all-europeanspackage-completed-good-consumers-good-growth-and-jobs-and-good-planet-2019-may22_en [https://perma.cc/PCV7-QKV2].

$$
\begin{aligned}
& { }^{21} \mathrm{Id} . \\
& { }^{22} \mathrm{Id} \text {. } \\
& { }^{23} \text { See, e.g., id. }
\end{aligned}
$$


the EU that aim to incorporate new technologies such as storage solutions and the creation of smart grids.

The article looks at how the priority of decentralized energy is being achieved in Latvia and Portugal. ${ }^{24}$ It begins by exploring the current domestic energy market in both countries, the current achievements in energy decentralization in terms of policy and legislation, as well as obstacles that have become apparent. It assesses new technologies and projects introduced to incentivize or further develop such technologies, namely smart metering systems, electric mobility, demand response, and electricity storage technologies. The article also looks at data protection concerns, the interconnection between the electricity markets of Portugal and Spain, and the possibility of a place in the market for the new clean energy sources. Based on the analysis of the electricity market of Latvia and Portugal, the article concludes with the domestic reality in both countries. As such, the conclusion outlines a set of recommendations to facilitate the introduction of new technologies in the energy sector and how to further implement the decentralization of the electricity market.

\section{LATVIA}

\section{A. Electricity Market}

\section{i. Key figures and statistics on energy and electricity}

According to data provided by the International Energy Agency, energy consumption in Latvia saw a general drop between 1990 and 2017.25 Examining each energy source separately, one can observe that consumption of all energy sources' decreased independently, with the optimistic exception of biofuels and waste, whose consumption evolved significantly, from 616 kilotonnes of oil equivalent (ktoe) in 1990, up to 1,007 ktoe in 2017.26 Oil products have had almost at all times the

${ }_{24}^{24}$ See generally R. Leal-Arcas et al., Energy decentralization in the European Union, Queen MARY U. of London, Sch. OF L. Legal Stud. Res. PAPER No. 307/2019, pp. $1-55$.

$\begin{array}{cccccc}25 & \text { INT'L ENERGY AGENCY, Data and statistics } & \text { and } \\ \text { https://www.iea.org/statistics/?country=LATVIA\&year=2017 } & \text { acategory=Energy\%20consu }\end{array}$ mption\&indicator $=$ TFCbySource $\&$ mode $=$ chart\&dataTable=BALANCES

[https://perma.cc/M9WT-X72A] (last viewed Oct. 16, 2020) (showing the total final consumption (TFC) by source, Latvia 1990-2017 in IEA's World Energy Balances).

${ }^{26} I d$. 
highest consumption, evolving from 2,066 ktoe in 1990 to 1,428 ktoe in 2017, even when they reached their lowest consumption levels, with 1,095 ktoe in $1999 .{ }^{27}$ Their consumption was surpassed only briefly by heat, with 1,935 ktoe in 1991 versus oil products' 1,897; however, since then heat witnessed a sharp drop, with only 605 ktoe consumed in $2017 .{ }^{28}$ Electricity and natural gas consumption have remained relatively steady yet declining, with 715 and 698 ktoe respectively in 1990, evolving into 558 and 328 ktoe respectively in 2017. ${ }^{29}$ Last in consumption is coal, dropping from 312 ktoe in 1990 to only 37 ktoe in $2017 .{ }^{30}$

Regarding renewables, there has been a remarkable progress in their inclusion in the Latvian energy mix, as per Sustainable Development Goal 7.31 While they were a mere $17.57 \%$ of the country's energy consumption in 1990, they progressed to become more than double in 2016, with the renewables' share being $38.48 \% .^{32}$ This is a very impressive positive development, especially considering that this percentage surpasses country's current obligations on renewable energy consumption as a member of the EU. ${ }^{33}$ Specifically, Directive 2018/2001 set a target for the EU Member States to collectively achieve a minimum of $32 \%$ of renewable energy consumption by 2032 and tailor their national policies accordingly in order to achieve it. ${ }^{34}$

Examining electricity final consumption in Latvia from 1990 to 2018 leads to several interesting observations. ${ }^{35}$ Consumption dropped from 9 terawatt hours (TWh) in 1990 to 7.2 TWh in 2018, demonstrating a low point in 1996 (5 TWh) but

${ }^{27} \mathrm{Id}$.
${ }^{28} \mathrm{Id}$.
${ }^{29} \mathrm{Id}$.
${ }^{30} \mathrm{Id}$.
${ }^{31} \mathrm{UN}$ General Assembly, Transforming our world: the 2030 Agenda for Sustainable Development, A/RES/70/1, (Oct. 21, 2015),

https://documents.un.org/prod/ods.nsf/home.xsp [https://perma.cc/4MKW-C8RV] (explaining that the United Nations' Sustainable Development Goals were introduced in 2015, aiming to crystallise the main targets within which sustainable development can be achieved globally. Sustainable Development Goal 7 states "Ensure access to affordable, reliable, sustainable and modern energy for all").

32 INT'L ENERGY AGENCY, supra note 25 (showing renewable share in final energy consumption (SDG 7.2), Latvia 1990-2016).

${ }_{33}^{3}$ See, e.g., id.

${ }_{34}$ Directive 2018/2001, of the European Parliament and of the Council of 11 December 2018 on the Promotion of the Use of Energy from Renewable Sources Directive L328/82, 2018 O.J. (L 328) 3.

35 Id. 
progressively rising after that. ${ }^{36}$ As for electricity consumption per sector, from 1990 to 2017 commercial and public services' consumption has seen a notable increase, from 163 ktoe in 1990 to 238 ktoe in 2017; commercial and public services' consumption is now far greater than even the next closest sectors. ${ }^{37}$ Those are industry and residential consumption, with 152 and 142 ktoe in 2017, respectively, while the lowest consuming sectors of the country are agriculture and forestry, consuming combined 16 ktoe in 2017, transport (9 ktoe), and fishing (1 ktoe). ${ }^{38}$ Interestingly, electricity consumption per capita has risen from $3.40 \mathrm{MWh}$ per capita in 1990 to $4 \mathrm{MWh}$ per capita in $2018 .^{39} \mathrm{It}$ reached its lowest point in 1994, similar to the data analysed above, when it reached $2 \mathrm{MWh} /$ capita, but has steadily increased from that point onwards. ${ }^{40}$

As far as Latvia's energy production is concerned, it has demonstrated a relatively steady increase in tons of oil equivalent produced, roughly doubling since 1990 to 2 Mtoe. ${ }^{41}$ On the other hand, the country's net energy imports have significantly declined, from 7 Mtoe in 1990 to 2 Mtoe in $2016 .{ }^{42}$ This results in a national total primary energy supply (TPES) reduced from 7.58 Mtoe in 1990 to 4.17 Mtoe in 2016-the TPES has generally been fluctuated between 4.00 and 4.50 Mtoe (roughly half of the 1990 amount) for the past decade. ${ }^{43}$

An important element helpful in understanding these figures is Latvia's population, which according to the United Nations' statistics, is decreasing faster than anywhere in the world, decreasing $18.2 \%$ from 2000 (2.38 million) to 2018 (1.95 million). ${ }^{44}$ This "loss" of one fifth of the country's population is partly due to its rapidly aging population, and partly to migration

36 INT'L ENERGY AGENCY, supra note 25 (showing filter energy topic for "Electricity and heat"; filter indicator for "Electricity final consumption"; filter country or region for "Latvia").

${ }^{37} I d$.

${ }^{38} I d$.

${ }^{39} I d$.

${ }^{40} \mathrm{Id}$.

${ }^{41}$ INT'L ENERGY AGENCY, supra note 25.

${ }^{42} I d$. (showing filter energy topic for "Imports/exports"; filter indicator for "Net energy imports").

${ }^{43}$ Id. (showing filter energy topic for "Energy supply"; filter indicator for "Total primary energy supply (TPES) by source").

${ }^{44}$ Gordon Sander, Latvia, a disappearing nation, PoliTiCo (Jan. 5, 2018) https://www.politico.eu/article/latvia-a-disappearing-nation-migration-population-decline/ [https://perma.cc/HF8A-BKHC]. 
in search of better economic prospects within the European Union. ${ }^{45}$

Latvia's electricity generation has been through several cycles in the past three decades, resulting in 2018 a slightly higher amount of electricity generation than in 1990 (6,724 GWh and $6,648 \mathrm{GWh}$, respectively). ${ }^{46}$ It is interesting to observe how the generation by source has evolved: coal, which held a slim percentage in the $1990 \mathrm{~s}$, never exceeding $3.1 \%$, has almost completely vanished from the mix today $(0.1 \%)$; and oil, which used to be the country's third highest electricity generation source until 2004 , providing up to $20.6 \%$ in 1996 , does not exist in the mix anymore. ${ }^{47}$ Wind and biofuels began to take their place in the mix in 1996 and 2001, respectively, starting to gain a noticeable percentage only after 2011, with $1.8 \%$ and $14 \%$, respectively. ${ }^{48}$ However, those amounts are far from comparable to the two largest sources of electricity for the country: hydropower and natural gas. ${ }^{49}$ From 1990 to 2018, hydropower has been dominating Latvia's electricity mix $(67.6 \%$ and $36.2 \%$ respectively), with its peak percentage being an impressive $74.5 \%$ in $1998 .{ }^{50}$ As natural gas has become a strong contender for the highest electricity generation source, progressing from $26.1 \%$ in 1990 to $47.9 \%$ in 2018, it surpassed even hydropower in 2011, 2014, 2015 and 2018.51

${ }^{45} I d$.

${ }^{46}$ INT'L ENERGy AGENCY, supra note 25 (filter energy topic for "Electricity and heat"; filter indicator for "Electricity generation by source"; filter country or region for "Latvia").

$$
\begin{aligned}
& { }^{47} \mathrm{Id} . \\
& { }^{48} \mathrm{Id} . \\
& { }^{49} \mathrm{See}, \text { e.g., } \mathrm{id} . \\
& { }^{50} \mathrm{Id} \text {. } \\
& { }^{51} \mathrm{INT} \text { L ENERGY AGENCY, supra note } 25 .
\end{aligned}
$$




\section{ii. Characteristics and Structure of Latvia's Electricity Market}

Despite being a former member of the Soviet Union and therefore an ex-communist country, Latvia has made significant steps toward opening its markets after the break-up of Soviet Union in 1991. Thanks to the reforms that followed the change of its regime, Latvia along with its Baltic neighbour Estonia are considered the "stars" of the transition from socialism to the market economy, as they succeeded in quickly reaching levels of development comparable to Central European countries. ${ }^{52}$

In 2007, Latvia began its progress toward a free electricity market to all electricity users, ${ }^{53}$ pursuant to its obligations under Directive 2003/54/EC of the European Parliament and of Council of 26 , issued June 2003.54 The opening of the market initially was limited to legal persons and eventually was completed in 2015, encompassing household consumers. ${ }^{55}$

The legal framework in which the Latvian electricity market operates is provided by the Latvian Electricity Market Law, passed by Saeima (the Latvian Parliament) in 2005 and subsequently amended to meet new developments, such as the aforementioned opening of the market in 2008, 2011, 2013, 2014, 2015 and 2016. ${ }^{56}$ As the Latvian Electricity Market Law states in Section 2, its purposes are:

1) to establish prerequisites for the operation of an efficiently functioning electricity market;

2) to ensure that, taking into account the requirements of laws and regulations, all energy customers are provided with electricity in a safe

\footnotetext{
${ }^{52}$ Havrylyshyn et al., 25 Years of Reforms in Ex-Communist Countries: Fast and Extensive Reforms Led to Higher Growth and More Political Freedom, CATO InstituTe, Policy Analysis No. 795 (July 12, 2016) https://www.cato.org/publications/policyanalysis/25-years-reforms-ex-communist-countries-fast-extensive-reforms-led [https://perma.cc/Y82R-6D55].

${ }^{53}$ AS Augstsprieguma Tikls, History, http://www.ast.lv/en/history [https://perma.cc/4G9Q-MHXW] (last viewed Mar. 20, 2020).

54 Diana Bride and Anda Zvaigzne, Electricity Market Development in Latvia, LATGALE NAT'L ECON. RES. J. OF SOC. SCI. (2016) No. 1(8), 5, 6.

${ }^{55} \mathrm{Id}$.

56 ELECTRICITY MARKeT LAW, (May 5, 2005), https://likumi.lv/ta/en/en/id/108834electricity-market-law [https://perma.cc/8VFD-QW7P].
} 
and qualitative manner, in the most efficient possible way for justified prices;

3) to ensure all customers with the right to choose an electricity trader freely;

4) to promote the production of electricity by using renewable energy resources;

5) to promote energy independence ensuring different suppliers of energy resources necessary for production of electricity. ${ }^{57}$

As for the scope of the Law's application, it regulates the production, transmission, distribution and trade of electricity as a free circulation commodity within Latvia and describes the duties of the electricity market participants and the electricity system participants within the national market. ${ }^{58}$ Furthermore, the Law defines the duties of the Latvian Ministry of Economics and the Public Utilities Commission (PUC or 'the Regulator', which the Ministry oversees) regarding the monitoring and regulation of the electricity market, and sets incentives for the increase of energy production from renewable sources. ${ }^{59}$

Pursuant to the Latvian Law On Regulators of Public Utilities, ${ }^{60}$ the Regulator is the authority responsible for licensing the provision of public utilities, and subsequently for supervising to which extent the public utilities must comply with the conditions of their license, quality and environmental protection requirements, technical specifications, standards, as well as contract provisions. ${ }^{61}$

Another important authority in the Latvian electricity market is Augstsprieguma Tīkls AS (or "AST"), an independent electricity transmission system operator. ${ }^{62}$ AST originally was part of Latvenergo, the national state-owned public utility

${ }^{57} I d$. at Section 2.

${ }^{58} I d$.

${ }^{59} I d$. at Section 3.

${ }^{60}$ Law on Regulators of Public Utilities, Legal Acts of the Republic of Latvia

(Nov. 7, 2000),

http://www.vvc.gov.lv/export/sites/default/docs/LRTA/Likumi/On_Regulators_of_Public_Ut ilities.pdf [https://perma.cc/ETX5-5ZTM].

${ }^{61}$ Mission, Objective and Functions, Sabiedrisko Pakalpojumu Regulēšanas

Komisija, https://www.sprk.gov.lv/en/content/mission-objective-and-functions [https://perma.cc/4K5B-NWUA] (last viewed Mar. 20, 2020).

${ }^{62}$ AS Augstsprieguma tikls, In Brief, http://www.ast.lv/en/content/brief [https://perma.cc/H3S8-24V5] (last viewed Mar. 20, 2020). 
company. ${ }^{63}$ After Latvenergo's legal unbundling in 2005 and eventually becoming an independent company in $2012,{ }^{64}$ AST's shares became wholly owned by the Latvian Ministry of Finance. ${ }^{65}$ As per the Electricity Market Law, AST is obliged to "facilitate the operation of the internal electricity market and cross-border trade, including the support of electricity exchanges development". ${ }^{6}$ It is also obliged to annually submit a report to the Ministry of Economics and the Regulator, assessing whether the transmission system supply and consumption and the safety and provision of State electricity supply conform with the national production capacities. ${ }^{67}$

While the aforementioned state-owned Latvenergo used to be a historical monopoly, after the liberalisation of the electricity market, new electricity producers have also claimed a place in it. ${ }^{68}$ Due to the delay in the electricity market's liberalisation along with public distrust, Latvenergo still holds a strong position in the market despite the competition. ${ }^{69}$ This can be visible by the fact that Latvenergo is the parent company and only shareholder of Sadales tīkls AS, ${ }^{70}$ the country's main distribution system operator (DSO), ${ }^{71}$ i.e., the national electricity network's maintainer and developer. ${ }^{72}$

The delay toward decentralisation is partly due to the European Union's 2009 Third Energy Package, ${ }^{73}$ EU granted a

63 See generally, e.g., AS AUGSTSPRIEGUMA TIKLS, supra note 53.

${ }^{64}$ European Commission, 2014 Country Reports - Latvia, European Union, https://ec.europa.eu/energy/sites/ener/files/documents/2014_countryreports_latvia.pdf (last viewed Mar. 20, 2020)

65 AS AUGSTSPRIEGUMA TIKLS , supra note 53.

66 ELECTRICITY MARKET LAW, $§ 13.1$ (2011) (Lat.),

http://extwprlegs1.fao.org/docs/pdf/lat73476ENG.pdf [https://perma.cc/7G5E-FW7W]; AS Augstsprieguma tīkls, Organisation of Electricity Market,

http://www.ast.lv/en/content/organisation-electricity-market [perma.cc/37DP-H9K8].

${ }^{67}$ ELECTRICITY MARKET LAW, $§ 15$ (2008) (Lat.),

http://extwprlegs1.fao.org/docs/pdf/lat73476ENG.pdf [perma.cc/3QL2-RCHF].

68 See, e.g., Diana Bride \& Anda Zvaigzne, Electricity Market Development in Latvia, 1 J. Soc. SCI. 8, 9 (2006).

${ }^{69} \mathrm{Id}$.

70 SADAlES TĪKLS AS, About Company, https://www.sadalestikls.lv/en/about-us2/who-we-are/sadales-tikls/ [perma.cc/XQW2-AU8D] (last viewed Oct. 16, 2020).

${ }^{71}$ EUR. CoMm'N., 2014 Country Reports-Latvia, 134 (2014)

https://ec.europa.eu/energy/sites/ener/files/documents/2014_countryreports_latvia.pdf [perma.cc/KV7Z-WR2P] (last viewed Oct. 16, 2020).

72 SADALES TīKLS AS, supra note 70.

${ }^{73}$ EUR. CoMM'N, Third Energy Package, (Mar. 16, 2020), https://ec.europa.eu/energy/topics/markets-and-consumers/market-legislation/thirdenergy-package_en?redir=1\#content-heading-5 [perma.cc/6X5N-MF2U]. 
derogation specifically for Latvia. ${ }^{74}$ The EU granted the derogation because Latvia was an emergent gas market requiring a more gradually process toward unbundling, the "heart" of the package. ${ }^{75}$ However, the Latvian government does value decentralised energy production, as shown in its National Energy and Climate Plan of Latvia (The National Plan). ${ }^{76}$ The National Plan embraces the decentralisation and microgeneration into the energy network, as long as there is careful monitoring, sufficient planning and analysis of their operation and development, and ensured efficient balancing of the network capacities. ${ }^{77}$

Concerning cross-border interconnectivity, Latvia's market at the wholesale level is integrated directly with the markets of Estonia and Lithuania (the Baltic States) as well as with those of Finland, Denmark, Norway, and Sweden (the Scandinavian or Nordic countries) as of $2013 .{ }^{78}$ Additionally, the EU internal electricity market has included Latvia, since the approval of the Baltic Energy Market Interconnection Plan (BEMIP) in 2009. ${ }^{79}$ BEMIP is an initiative between the European Commission, Denmark, Germany, Estonia, Latvia, Lithuania, Poland, Finland, and Sweden (and Norway as an observer), aiming to synchronise the Baltics' grid with the continental European network by 2025.80 The initiative's members signed an initial Memorandum of Understanding in 2009, and a new one followed in 2015, to further BEMIP's scope to "security of supply, energy efficiency, renewable energy and the integration of the Baltic States' electricity network into the continental European network, including their synchronous operation."81 The BEMIP's should end the Baltic's energy isolation through projects of common interest (PCIs), as communicated in the European Commission's European Energy Security Strategy from May

74 EuR. CoMm'N, supra note 71, at 134.

${ }^{75} \mathrm{Id}$.

${ }^{76}$ Commission Regulation 2018/1999 of Dec. 11, 2018, Governance of the Energy Union and Climate Action, O.J. (L 328); EUR. CoMm'N, National Energy and Climate Plan of Latvia 2021-2030: For Submitting to the European Commissions for Evaluation, 138 (2018) https://ec.europa.eu/energy/sites/ener/files/documents/latvia_draftnecp_en.pdf [perma.cc/5SVN-4ULY] (last viewed Oct. 16, 2020).

77 Id. at 144 .

${ }^{78}$ Augstsprieguma tīkls AS, supra note 53.

${ }^{79} I d$.

${ }^{80}$ EUR. Comm’N, Baltic Energy Market Interconnection Plan, (last updated Oct. 17, 2019) https://ec.europa.eu/energy/topics/infrastructure/high-level-groups/baltic-energymarket-interconnection-plan_en?redir=1\#content-heading-1 [perma.cc/YPQ6-5GUR].

${ }^{81} I d$. 
2014. ${ }^{82}$ Currently, the Baltic states have high levels of interconnection, but there is still untapped potential toward further integration and synchronisation with continental Europe. ${ }^{83}$

\section{iii. Energy Security}

Latvia, along with the other Baltic states, Estonia and Lithuania, plan to integrate into the European energy grid by 2025. ${ }^{84}$ This development will significantly shift Latvia's energy dependence from Russia to Europe. Historically, Latvia's electricity system, along with those of Belarus and Latvia's fellow Baltics Lithuania and Estonia, have been heavily interconnected with Russia's energy grid, despite the Soviet Union's dissolution. ${ }^{85}$ Geopolitically speaking, Russia's ability to be a force of stabilisation in Eurasia is doubt since the 'Five Day War' in August 2008.86 Additionally, the management of Gazprom, the powerful Russian state-owned energy group, is intrinsically linked with the Russian government, providing little confidence in terms of maintaining a healthy market economy devoid of favouritism. ${ }^{87}$ One can therefore see Latvia's transition toward the European grid is clearly in its best interest in terms of connecting it with the market of a more politically stable and reliable force as the EU and promotes its energy security by reducing its dependence on Russia. 88

It is worth noting that while this shift from one electricity grid to another has not been completed, there have been a number of cyberattack threats toward the Baltic grid, originating from hackers based in Russia, which if successful could endanger

\footnotetext{
82 EUR. COMM'N, European Energy Security Strategy (2014), https://www.eesc.europa.eu/resources/docs/european-energy-security-strategy.pdf [perma.cc/TA8E-RQ6G] (last viewed Oct. 16, 2020).

${ }^{83}$ EUR. COMM'N, supra note 80.

${ }^{84} \mathrm{Id}$.

85 EUR. COMM'N, supra note 71, at 137.

86 Rafael Leal-Arcas et al., The European Union and its Energy Security Challenges, 8 J. WorLd ENERGY L. \& Bus. 1, 29-31 (2015).

${ }^{87} \mathrm{Id}$. at $33-34$.

88 Augstsprieguma tīkls AS, Synchronisation with Europe, https://www.ast.lv/en/projects/synchronisation-europe [https://perma.cc/37DP-H9K8] (last viewed Mar. 26, 2020).
} 
the entire region's energy supply. ${ }^{89}$ In order to counter them and minimize the countries' vulnerability against potential hacking attempts, cybersecurity has become a high priority for the Baltic States' authorities, resulting in them signing in October 2019 an agreement with the United States involving the Baltic energy grid's protection from cyberattacks through strategic and technical support. ${ }^{90}$

\section{B. How smart is Latvia's electricity system?}

\section{i. Self-generation}

An important factor indicating just how "smart" and conducive to decentralization Latvia's electrical infrastructure is now, is the role of energy prosumers in it. Prosumers are defined as "self-generating energy providers, whether households or energy communities. ${ }^{91}$ Individuals contribute to the energy supply in their vicinity via their own installed renewable energy capacity, more often than not solar roofing, wind energy, or combined heat and power." 92 While there is no official definition of the term "prosumer" (a term derived from the words "produce" and "consume") from the European Union bodies, they are alternatively described in relevant documents as "active energy consumers," holding the potential to revolutionize the way electricity systems have been traditionally functioning until today. ${ }^{93}$

Residential electricity generation in Latvia is not addressed, until today at least, by a particular piece of legislation, as so far, as in the other Nordics and Baltics, prosumers are a marginal phenomenon. ${ }^{94}$ What has been preferred is to address prosumers within the national framework, specifically within the Latvian Energy Law and its Electricity

89 See, e.g., Euractiv, US to help secure Baltic energy grid against cyber-attacks

(Oct. 7, 2019), https://www.euractiv.com/section/energy/news/us-to-help-secure-balticenergy-grid-against-cyber-attacks/ [https://perma.cc/CX8G-JU7Q].

${ }^{90} I d$.

91 Rapheal Leal-Arcas, et al., Prosumers as New Energy Actors, Africa-EU Renewable Energy Research and Innovation Symposium 2018 (RERIS 2018).

${ }^{92} I d$.

${ }^{93}$ Nikolina Sajn, Electricity 'Prosumers', European Parliament (Nov. 2016).

${ }_{94}$ Framework Conditions for Flexibility in the Electricity Sector, Flex4RES Flexible Nordic Energy Systems, 6 (Dec. 2016). 
Market Law. ${ }^{95}$ In the Latvian Energy Law, prosumers are addressed under the term "autonomous producer," which is defined as "a merchant, an energy supply merchant or a natural person which produces electricity or thermal energy for the purpose of consuming it for personal needs or local heating supply needs." 96 According to the Latvian Electricity Tax Law, passed after the country's entrance in the EU, in compliance with the relevant Directives on energy products taxation, the autonomous producers "generating and consuming electricity for their own needs" fall out of the law's scope of application, provided that their electricity generation is smaller than two megawatts (MW). ${ }^{97}$

As far as the prosumers' compensation is concerned, the current policy followed by Latvia mandates that when energy is transferred from a household to the power grid, this amount is subsequently deducted by the household's invoice for the next billable month. ${ }^{98}$ It is a policy based on the use of the net settlement system, which is in turn based on a metering system permitting net accounting of the electricity transferred and used. ${ }^{99}$

\section{ii. Investment and $R \& D$}

A popular practice to encourage the development of renewable energy projects has been the application of feed-in tariffs (FiT). ${ }^{100}$ A national economic policy on FiT usually involves appealing terms such as long-term agreements with renewable energy producers and guaranteed pricing, tied to the renewable energy production costs, in order to attract investments from this form of energy and therefore the diversification of the energy mix. ${ }^{101}$

Currently, FiT is a dominant practice in all Baltic countries except Latvia, as the FiT that had been in effect there since 2007 is on hold due to concerns of corruption and the

\footnotetext{
95 EUR. Comm'N, Study on "Residential Prosumers in the European Energy Union”, 34 (May 2, 2017).

${ }^{96}$ Latvian Energy Law, Chapter I, Section 1, Term 32 (2014).

${ }^{97}$ Latvian Electricity Tax Law, Section 2, (3).1.

${ }^{98}$ Eur. Comm'n, supra note 95.

${ }^{99} \mathrm{Id}$.

${ }^{100}$ See, e.g., id.

${ }^{101} I d$.
} 
apparent lack of transparency. ${ }^{102}$ The hold is due to last until at least until January 2020, when there will be a judgement on the relevant State Aid case, meaning, until then, the government is hesitant to provide its support in new RES projects. ${ }^{103}$ In spite of the temporarily inconvenient setback, going forward, Latvia is certainly open to investments on a national and international level in order to promote low-carbon energy, placing much emphasis in the relevant technological research and development $(\mathrm{R} \& \mathrm{D})$, which is definitely a positive sign for the future of smart tools and technologies in the country. ${ }^{104}$

In a recent meeting in October 2019, the environment ministers of Latvia, Estonia and Lithuania signed a joint Baltic States Climate Declaration, where they affirmed their countries' common vision regarding to tackling climate change. ${ }^{105}$ Apart from committing once again to cross-border cooperation to achieve climate neutrality, they addressed the EU to request adequate funding from its budget in its following multi-year financial plan. ${ }^{106}$

For the next decade, the European Union has already been set to provide Latvia with financial aid to support the implementation of its energy and climate plan, through a variety of programmes and funds, such as the Multiannual Financial Framework for 2021-2027, InvestEU, Horizon Europe, the Connecting Europe Facility, the European Regional Development Fund (ERDF), the Cohesion Fund (CF) and the LIFE Programme for the Environment and Climate Action. ${ }^{107}$ Some of them, such as Horizon, are particularly focused on promoting research and innovation, an essential part of the development of smart technologies. ${ }^{108}$ Research and innovation in smart energy is also recognized as a priority area in the Research and Innovation Strategy of Latvia for Smart Specialisation (RIS3). ${ }^{109}$

\footnotetext{
102 FLEX4RES, Framework Conditions for Flexibility in the Electricity Sector, Flexible Nordic Energy Systems, 53 (Dec. 2016).

${ }_{103} I d$. at 54.

104 See, e.g., id.

105 BALTiC NEWs NETWORK, Baltic environment ministers sign joint climate declaration, (Oct. 31, 2019), https://bnn-news.com/baltic-environment-ministers-sign-jointclimate-declaration-206882 [https://perma.cc/54PH-JZGT].

${ }^{106} I d$.

107 Eur. Comm'N, National Energy and Climate Plan of Latvia, Riga, 67-74 (2018).

$108 I d$. at 69.

${ }^{109} I d$. at $40-41$.
} 
According to the first RIS monitoring report in 2017, while some relevant structural reforms have taken place in Latvia, such as the development of appropriate conditions to introduce contributions from the EU and national sources directed to science and innovation, eventually investments in the key area of research and development (R\&D) had failed to increase, and the national contributions were not amassed as per the plan. ${ }^{110}$

Apart from funding issues, R\&D in Latvia is impaired because of the lack of commercialization opportunities, as well as the lack of cooperation, both on the international and national level, between science, technological and educational institutions, state and industry. ${ }^{111}$ In order to tackle the above, in the Latvian National Energy and Climate Plan for 2021-2030 there are provisions for augmenting the $R \& D$ investments and promoting innovation, such as the introduction of R\&D tax credit and the establishment of a cross-sector to connect business and research. ${ }^{112}$

\section{SMART METERS}

Smart meters are an important technological tool facilitating energy consumers to monitor, in real time, the amount of energy they are consuming. ${ }^{113}$ This function positively impacts their electricity bills and allows them a certain degree of flexibility, in contrast with traditional electricity metering. ${ }^{114}$ They are sophisticated tools, apart from providing accurate information to their users, also aiding them to control their energy usage, and can empower them to become active players in the energy market through the use of their smart grids. ${ }^{115}$ As requested by the European Directive 2009/72/EC, until 2020, where this tool has been made available and assessed positively,

${ }^{110} I d$. at $118-19$.

111 Id. at $122-23$.

112 Id. at $139-42$.

${ }^{113}$ FLEX4RES, Framework Conditions for Flexibility in the Electricity Sector, Flexible Nordic Energy Systems, 13 (Dec. 2016).

${ }_{114} I d$.

${ }^{115}$ Leal-Arcas, supra note 91; Mpholo M., Steuerwald D., Kukeera T., Africa-EU Renewable Energy Research and Innovation Symposium 2018 (RERIS 2018), https://link.springer.com/chapter/10.1007/978-3-319-93438-9_12 [https://perma.cc/N8WTRJMM]. 
at least $80 \%$ of consumers should be equipped with smart meters. ${ }^{116}$

As for Latvia's approach on the matter, the national transmission system operator has planned to install smart meters for all its customers by 2022.117 There has been steady progress toward that direction, with approximately 110,000 meters being replaced yearly, resulting in half a million smart meters installed by September 2018.118 According to the National Plan for 2021-2030, it is planned to promote their use even further, by raising consumer awareness on the benefits of their use. ${ }^{119}$

\section{i. Electric vehicles}

The European Union recognizes electric vehicles $(\mathrm{EVs})$ as a promising alternative to conventional, fossil fuel consuming vehicles supporting the progress toward sustainable, decarbonised transport in Europe. ${ }^{120}$ This is visible from a series of official EU legal acts, such as the 2014 Directive on the deployment of alternative fuels infrastructure, ${ }^{121}$ the 2016 Regulation on emissions from light passenger and commercial vehicles, ${ }^{122}$ the 2016 European Parliament Resolution on a European strategy for low-emission mobility, ${ }^{123}$ and the 2019 Regulation on $\mathrm{CO} 2$ emission performance standards for new

116 Directive 2009/72/EC of the European Parliament and of the Council of 13 July 2009 Concerning Common Rules for the Internal Market in Electricity and Repealing Directive 2003/54/EC, O. J. (L Annex I), 2.

117 EUR. Comm'N, supra note 107.

${ }^{118} I d$. at 59.

${ }^{119} I d$. at 142.

120 EuR. ENV'T AGEncy, Electric vehicles in Europe, EEA Report No 20/2016, Copenhagen, 9 2016/ Luxembourg: Publications Office of the European Union (2016) [doi: 10.2800/100230].

${ }^{121}$ Directive 2014/94, of the European Parliament and of the Council of 22

October 2014, on the Deployment of Alternative Fuels Infrastructure, https://eurlex.europa.eu/legal-content/en/TXT/?uri=CELEX\%3A32014L0094 [https://perma.cc/56ATMFEP].

122 EU Commission Regulation No. 2016/427 of 10 March 2016, amending Regulation (EC) No 692/2008 as regard Emissions from Light Passenger and Commercial Vehicles (Euro 6), https://eur-lex.europa.eu/legalcontent/EN/TXT/?uri=CELEX\%3A32016R0427 [https://perma.cc/JWQ9-RTHF].

${ }^{123}$ European Parliament resolution No. 2016/2327 of 14 December 2017, on a European Strategy for Low-Emission Mobility, http://www.europarl.europa.eu/doceo/document/TA-8-2017-0503_EN.html [https://perma.cc/R76V-F9G6]. 
vehicles, ${ }^{124}$ altogether creating a roadmap toward a future where all transport will produce minimum or zero carbon emissions.

In view of the above, one of the objectives of the Latvian National Energy and Climate Plan for the next decade is to endorse alternative fuels and minimize the negative environmental impact caused by transport, through the promotion of this type of vehicles. ${ }^{125}$ This is a target covering two of the key five dimensions of the Energy Union 126: energy efficiency and decarbonisation, along with the sub-dimension of renewable energy. ${ }^{127}$ The main policy steps necessary in order to accomplish that objective include the simplification of the administrative procedure to establish non-public electric vehicle charging points, the promotion of EV purchases, and the improvement of the relevant regulatory framework on EVs and their charging infrastructure, which are included in the country's Alternative Fuels Development Plan 2017-2020 (“AFDP 2020”).128

Those steps appear appropriate, considering the primary reason reported to be discouraging Latvians from purchasing EVs is their forbiddingly high price, which renders them a somewhat luxurious item for the average Latvian household, despite its benefits - one must remember that Latvia's GDP per capita is quite lower of its fellow Member States. ${ }^{129}$ Although the benefits offered currently to electric vehicle owners are not negligible, including tax exemptions and use of public transport lanes, the

${ }_{124}$ Regulation (EU) 2019/631 of the European Parliament and of the Council of 17 April 2019 Setting CO2 Emission Performance Standards for New Passenger Cars and for New Light Commercial Vehicles, and Repealing Regulations (EC) No 443/2009 and (EU) (No 510/2011) https://eur-lex.europa.eu/legal-

content/EN/TXT/?uri=CELEX\%3A32019R0631 [https://perma.cc/6XYM-ALFM].

${ }^{125}$ EUR-LEX, A Framework Strategy for a Resilient Energy Union with a

Forward-Looking Climate Change Policy, 1 COM (2015) 80 final (Feb. 25, 2015) https://eur-lex.europa.eu/legal-content/EN/TXT/?uri=COM:2015:80:FIN

[https://perma.cc/UP8H-BJQN] (Aiming to endorse EU's energy security, along with climate resilience and innovation, by creating "an integrated, continent-wide energy system").

${ }^{126} I d$.

${ }^{127}$ Regulation (EU) 2019/631, of the European Parliament and of the Council of 17 April 2019 and European Commission, https://ec.europa.eu/energy/en/topics/energystrategy-and-energy-union/building-energy-union [https://perma.cc/96TL-5EBD].

128 POLSIS, National Energy and Climate Plan of Latvia 2021-2030 \& Latvian Alternative Fuels Development Plan 2017-2020, (April 25, 2017)

http://polsis.mk.gov.lv/documents/5893 [https://perma.cc/J5CE-BPC9] (last viewed Oct. 16, 2020).

${ }^{129} I d$. at 88 . 
price reduction to make them accessible to the wider public is critical. ${ }^{130}$

\section{ii. Demand response}

Demand response is defined as the intentional modification of normal consumption patterns by end-use customers in response to incentives from grid operators, designed to lower electricity use at times of high wholesale market prices or when system reliability is threatened. ${ }^{131}$ It requires consumers to either actively respond to the operator's signals or alternatively, to employ automated solutions to enter into contracts with service providers ${ }^{132}$ By their active involvement in demand response, those consumers can differentiate from their traditionally passive role and become prosumers. ${ }^{133}$

Within the EU's legislative framework, the 2012 Energy Efficiency Directive (part of the EU's Clean Energy Package ${ }^{134}$ ) recognizes the importance of demand response in its preambles, as it promotes energy savings and optimal use of networks, and therefore stresses the need to improve the conditions necessary for it to take place and for consumers' access to it. ${ }^{135}$ For this to be achieved, certain EU member states' obligations have been mapped out. In the Energy Efficiency Directive, member states are called to remove incentives related to transmission and distribution tariffs that could hold behind either overall energy

${ }^{130} I d$. at $88-89$.

131 SETIS MAgazIne, Demand response - empowering the European consumer, SMART GRIDS, (Mar. 2014), https://setis.ec.europa.eu/publications/setis-magazine/smartgrids/demand-response-empowering-european-consumer [https://perma.cc/932V-Q67Z].

${ }^{132} I d$.

${ }^{133}$ Leal-Arcas et al, supra note 86.

134 Eur. Comm'N, Clean Energy for all Europeans Package (Dec. 12, 2019), https://ec.europa.eu/energy/en/topics/energy-strategy-and-energy-union/clean-energy-alleuropeans [https://perma.cc/7VMX-RPGY] (containing a set of eight legislative acts functioning as EU's rulebook regarding to facilitating the energy transition and complying with the Paris Agreement).

135 EU Directive No. 2012/27/EU of the European Parliament and of the Council of 25 October 2012, on Energy Efficiency, amending Directives 2009/125/EC and 2010/30/EU and repealing Directives 2004/8/EC and 2006/32/EC, preambles (44), (45), https://eurlex.europa.eu/LexUriServ/LexUriServ.do?uri=OJ:L:2012:315:0001:0056:EN:PD F [https://perma.cc/4YD4-EPKL]. 
efficiency or "participation of demand response, in balancing markets and ancillary services procurement."136

Additionally, per the EU Regulation on the Governance of the Energy Union, national climate and energy plans in all markets should include objectives and measures to ensure the non-discriminatory participation of demand response, including via aggregation. ${ }^{137}$

No specific measures for the promotion of Demand Response are currently mentioned in the Latvian NEEAP (National Energy Efficiency Action Plan).138 However, Latvia does recognize how important the development of such services is, and has explicitly stated in its National Energy and Climate Plan that creating an appropriate legal framework for that is a priority. ${ }^{139}$ This objective echoes the conclusions drawn from a 2017 working group between the Baltic and Finnish transmission system operators Litgrid AB, Elering AS, and AS Augstsprieguma tīkls, aiming for a harmonized Baltic region approach toward demand response, realized through a common framework. ${ }^{140}$

\section{iii. Electricity storage}

In the European Union legal framework, there was no formal definition of electricity storage until recently, which resulted in complications, namely hesitation on behalf of transmission and distribution company investment in storage. ${ }^{141}$ In the latest addition to the EU's Clean Energy Package, a 2019 Directive on common rules for the internal market for electricity defined energy storage in the electricity system as "deferring the final use of electricity to a moment later than when it was

${ }^{136}$ EU Directive No. 2012/27/EU of the European Parliament and of the Council of 25 October 2012 on energy efficiency, Article 15, paragraph 4.

${ }_{137}$ Council Regulation 2018/1999, supra note 76, at art. 23.

138 Paolo Bertoldi, Paolo Zancanella \& Benigna Boza-Kiss, Demand Response status in EU Member States, JRC Science for Policy Report, 2016, at 27.

139 POLSIS, supra note 128 , at 60.

$140 I d$. (Noting that hopefully those plans will not exist solely in theoretical discussions anymore and will soon become part of Latvia's practice).

${ }^{141}$ EUROPEAN PARLIAMENT, Energy Storage: which market designs and regulatory incentives are needed?, DiRECTORATE GEN. FOR INTERNAL POLICIES, POL'y DEP'T A: ECON. AND SCI. POL’Y, 46, SEC (Oct. 2015), http://www.europarl.europa.eu/RegData/etudes/STUD/2015/563469/IPOL_STU(2015)5634 69_EN.pdf [https://perma.cc/WY6Y-NC99]. 
generated, or the conversion of electrical energy into a form of energy that can be stored, the storing of such energy, and the subsequent reconversion of such energy into electrical energy or use as another energy carrier." 142

Latvia currently does not have a developed framework concerning electricity storage and generally has not seen much technological development within that field. ${ }^{143}$ As in the case of electric vehicles discussed above, decentralized energy storage costs are still deemed prohibitively expensive, especially considering the financial situation in Latvia relative to other EU member states. ${ }^{144}$ As per the national climate and energy plan, Latvia is optimistic that if all goes as planned, investments from EU funding sources such as the Innovation Fund and the Modernisation Fund will result in the development of appropriate energy storage projects beginning in 2020.145 The plan further states that no specific prohibitions for the introduction and use of renewable energy technologies are in force pursuant the EUmandated elimination of discriminations, but those technologies are always subject to geographic and possible environmental, biodiversity, societal, or territorial conditions. ${ }^{146}$

\section{iv. Data protection and cybersecurity concerns}

Naturally, as technologies and intelligent devices gain more ground in citizens' everyday life, valid concerns arise of government and other public or even private entity abuse. This power derives from an entity's facilitated access to otherwise secure information about smart electricity consumers that the consumer would prefer to remain strictly private, rendering consumers vulnerable against the state and anyone else in possession of their data.

142 Council Directive 2019/944, art. 2(59), 2019 O.J. (L 158/125) https://eurlex.europa.eu/legal-content/EN/TXT/?uri=CELEX\%3A32019L0944 [https://perma.cc/7796763D] (explaining EU Member States are required to prepare national climate and energy plans, as per the EU Regulation on the Governance of the Energy Union. Those plans have to include the country's national objectives and measures to ensure, among others, the non-discriminatory participation of energy storage, including via aggregation, in all energy markets.)

${ }^{143}$ Flex4RES, supra note 95 at 6.

144 Sajn, supra note 93 at 4.

${ }^{145}$ EUR. COMM'N, supra note 71, at 73-74.

${ }^{146} I d$. at 36,59 . 
Additionally, the automation and digitalization of more and more services exposes providers and consumers alike to another danger cyberattacks. The proliferation of the "Internet of Things" smart device has opened many possible routes through which the function of a grid can be compromised: electric vehicles, smart meters, thermostats and home appliances, all could potentially be vulnerable access points of a targeted smart grid. ${ }^{147}$ Latvia especially has been no stranger to hacking attempts despite efforts to mitigate, and the threat remains within the realm of possibility. ${ }^{148}$

Recent EU legislation should be of help in tackling data protection concerns. In May 2018, a Regulation of the European Parliament initiated the landmark General Data Protection Regulation (GDPR), the dawning of "a new era" in the field of data protection of natural persons. ${ }^{149}$

The GDPR's main provisions regulate the processing of personal data in compliance with six quality principles. ${ }^{150}$ First, data must be lawfully, fairly, and transparently processed in relation to the subject; second, they need to be gathered "for specified, explicit and legitimate purposes and not further processed in a manner incompatible with those purposes;" and third, the processing must be limited to an appropriately relevant extent. ${ }^{151}$ The other three provisions require accuracy, the keeping of the data in an identifiable location only for the necessary amount of time, and security. ${ }^{152}$

Additionally, either the data subject must give consent, the data must be necessary for the performance of a contract with the data subject, necessary for compliance with a legal obligation, necessary to protect the vital interests of the data subject, necessary to perform a task in the public interest or the exercise of official authority, or, alternatively, the controller or other third-party recipient must have "legitimate interests" that do not conflict with fundamental rights of privacy. ${ }^{153}$

\footnotetext{
147 Yasin Yilmaz \& Suleyman Uludag, Mitigating IoT-based Cuberattacks on the Smart Grid, IEEE INT'L CONF. ON MACHINE LEARNING AND APPLICATIONS (2017), at 517.

148 See, e.g., id.

149 EUR. Comm'N, A new era for data protection in the EU - What changes after May 2018 (May 2018), https://ec.europa.eu/commission/sites/beta-political/files/dataprotection-factsheet-changes_en.pdf [https://perma.cc/FAF6-T2FX].

${ }^{150}$ Commission Regulation 2016/679, art. 5, 2016 O.J. (L 119) 1 (EC).

${ }_{151} I d$.

${ }_{152} I d$.

${ }^{153} I d$. at art. 6.
} 
Enacted regulations, as per EU law, are automatically binding on member states, and considered part of the member states' own legislation. ${ }^{154}$ It is then up to each government's discretion to decide whether to update national legislation to comply with the regulation and avoid possible contradictions between its laws. ${ }^{155}$ This is what the Latvian government opted for in July, 2018, when Latvia became the first Baltic nation to adopt legislation regarding the GDPR by enacting the Law on Personal Data Processing 156 to replace the outmoded Law on the Protection of Personal Data of Natural Persons (the "DPA") of $2000 .{ }^{157}$

The authority responsible for enforcing the new law is the Data State Inspectorate of Latvia (DSI), Latvia's national supervisory representative in the European Data Protection Board, EU working groups, and other international forums. ${ }^{158}$

While the aforementioned DPA Law was in force, there had been approximately 600 inspections related to the law's violation in the course of sixteen years. ${ }^{159}$ There had been a violation in less than a quarter of the cases inspected, and eventually a fine was imposed in a tenth of the cases inspected, usually ranging in amounts disproportionately low to the fining capacity of the DSI (up to $€ 14,000$ for a single case). ${ }^{160}$ Since the enactment of the GDPR and the Latvian Law on Personal Data Processing, the amount of complaints reached a "record number," yet the DSI has not imposed many penalties, generally only

154 EUR. COMm'N, Applying EU law - EU law and its application (2019) https://ec.europa.eu/info/law/law-making-process/applying-eu-law_en\#eu-law [https://perma.cc/K3ES-RP36]; EUR. COMM’N, Types of EU law - Types of EU legal acts (2019) https://ec.europa.eu/info/law/law-making-process/types-eu-law_en. [https://perma.cc/89A7-NYKX].

${ }^{155} \mathrm{Id}$.

${ }^{156}$ Latvia has adopted the law on personal data processing, EuroCloud, July 31, 2018), https://eurocloud.org/news/article/latvia-has-adopted-the-law-on-personal-dataprocessing/ [https://perma.cc/J5ET-ZJMX].

157 Ellex Klavins, Data Protected - Latvia, Linklaters (Aug 2018), https://www.linklaters.com/en/insights/data-protected/data-protected---latvia\#security [https://perma.cc/2JS3-Y26T].

${ }_{158}$ Id.; International Cooperation, Data State Inspectorate of the Republic of Latvia (July 26, 2017, 1:39 PM), https://www.dvi.gov.lv/en/personal-data-protection2/international-cooperation/ [https://perma.cc/3NHB-XKPS].

159 Klavins, supra note 157.

${ }^{160} \mathrm{Id}$. 
imposing fines up to $€ 2,000,{ }^{161}$ with the recent exception of a $€ 7,000$ fine in August 2019. ${ }^{162}$ The authority justified its relatively benign approach by the overwhelming number of complaints, opting to mainly consult in order to guarantee the GDPR is properly implemented in the first year after its application, rather than punish noncompliance. ${ }^{163}$

In light of the above, Latvia does have the appropriate legislative tools to address possible cases of data protection violations by smart electricity technologies. Considering the technological advancements taking place every day, and the potential risks they could pose, Latvian authorities should definitely aim to progress in terms of enforcement.

The European Union emphasized smart grid cybersecurity with the creation of a Smart Grids Task Force in 2017, which in June 2019 submitted an energy-specific report on cybersecurity. ${ }^{164}$ The report proposed a Network Code on Cybersecurity to complement the 2019 EU Cybersecurity Act, and concluded by suggesting a holistic approach to mitigation, demanding the collaboration of public and private actors, and the building of trust among EU member states and among international allies. ${ }^{165}$ Furthermore, in October 2019, the European Parliamentary Research Service presented a brief on cybersecurity of critical energy infrastructure before the European Parliament, also stressing the urgency of "strong sociocyber-physical security measures and policies, notably in the electricity sector."166

The Latvian national climate and energy plan acknowledges the danger of cyber-attacks, and states that one

161 Anna Vladimirova-Krjukova, The GDPR One Year On, Ius Laboris (June 25, 2019), https://www.lexology.com/library/detail.aspx?g=b22dc949-5d51-4e66-a03fb6b88edc239f [https://perma.cc/TP9D-LMBZ].

162 Eur. Data Protection BoARD, Data State Inspectorate of Latvia imposes a financial penalty of 7000 euros against online retailer (Sept. 3, 2019), https://edpb.europa.eu/news/national-news/2019/data-state-inspectorate-latvia-imposesfinancial-penalty-7000-euros-against_en [https://perma.cc/2ATS-WNCD].

${ }^{163}$ See Krjukova, supra note 161.

${ }_{164}$ EUR. UnION, Smart Grid Task Force Expert Group 2, Final Report, 5 (June

2019), https://ec.europa.eu/energy/sites/ener/files/sgtf_eg2_report_final_report_2019.pdf [https://perma.cc/GH8Y-7DNZ].

$165 \mathrm{Id}$. at 100.

${ }^{166}$ Gregor Erbach \& Jack O'Shea, Cybersecurity of Critical Energy

Infrastructure, Eur. Parliamentary res. Serv., 7 (Oct. 2019),

http://www.europarl.europa.eu/RegData/etudes/BRIE/2019/642274/EPRS_BRI(2019)64227

4_EN.pdf [https://perma.cc/974D-XRM5]. 
must be vigilant of cybersecurity issues when developing energy projects. ${ }^{167}$ But, apart from rather brief statements, no concrete strategy to prevent or at least minimize the risk of cyber-attacks is announced in the plan. ${ }^{168}$

\section{PORTUGAL}

\section{A. Energy Profile}

Compared to the EU-28 countries, Portugal had the seventh highest energy dependence in 2015.169 The country relies on energy imports of oil and gas from various other countries in order to meet its energy needs, with the biggest share of imports from Angola.170 Portugal decreased its energy dependence on fossil fuel imports with an increase of renewable energy production, but dependency on imports for energy supply remains excessively high. ${ }^{171}$ For context, Portugal imported 2,710 Gigawatt-hours of electricity in the first four months of $2019 .{ }^{172}$

\section{B. Energy Production}

The energy produced in Portugal is enough to meet the needs of the population, but the country also imports electricity from Spain for commercial reasons. ${ }^{173}$ On the other hand, Portugal also exports its electricity production surplus to Spain. ${ }^{174}$ According to Redes Energéticas Nacionais (REN), in the first quarter of 2018, renewable energy provided for $61 \%$ of Portuguese energy consumption needs, (31\% from wind power, $24 \%$ from hydroelectric power, $5 \%$ from biomass and $1.1 \%$ from photovoltaic energy), while the remaining $39 \%$ of energy needs

${ }_{167}$ EUR. COMM'N, supra note 107.

168 See generally id.

${ }^{169}$ Carlos V. Miguel, Adélio Mendes and Luís M. Madeira, An Overview of the Portuguese Energy Sector and Perspectives for Power-to-Gas Implementation, MDPI Energies, Nov. 23, 2018, at 4.

${ }^{170} I d$. at 5 .

${ }^{171} I d$. at 4.

172 Mónica Carneiro Pacheco, et al., Electricity Regulation in Portugal: Overview, Thomson Reuters: Practical Law (Nov. 1, 2019).

${ }^{173}$ Miguel supra note 169 , at 4 .

${ }^{174} I d$. 
were met by non-renewable energy production ( $22 \%$ from natural gas and $17 \%$ coal). ${ }^{175}$

Portugal is one of Europe's leaders in promoting the production of energy from renewable sources due largely to strategic efforts to replace fossil fuels. ${ }^{176}$ The country plans to increase its renewable energy share to $40 \%$ by the year $2030 .{ }^{177}$ In the period 2005-2015, the amount of renewable energy produced increased $50.64 \%$ from 3392 to 5110 kilotons of oil equivalent (ktoe), as seen in Figure 1. ${ }^{178}$ Portugal produced 5.6 million tonnes of oil equivalent (Mtoe) energy in 2014 from a multitude of resources such as from biofuels and waste $(52.2 \%)$, hydropower $(23.9 \%)$, wind power $(18.5 \%)$, geothermal $(3.1 \%)$, and solar power $(2.3 \%)$, per the International Energy Agency in its 2016 report. ${ }^{179}$

Figure 1: Evolution of renewable energy production (ktoe) between 2005 and 2015 .

\begin{tabular}{cccccccc}
\hline Renewable Energy Type & $\mathbf{2 0 0 5}$ & $\mathbf{2 0 0 7}$ & $\mathbf{2 0 0 9}$ & $\mathbf{2 0 1 1}$ & $\mathbf{2 0 1 3}$ & $\mathbf{2 0 1 5}$ & $\boldsymbol{\Delta}(\mathbf{2 0 1 5} / \mathbf{2 0 0 5})$ \\
\hline Biofuels & 0 & 162 & 226 & 330 & 274 & 321 & - \\
Electricity $^{1}$ & 599 & 1265 & 1456 & 1872 & 2369 & 1927 & 3.2 \\
Biomass $^{2}$ & 2773 & 2891 & 3019 & 2571 & 2812 & 2781 & 1.0 \\
Other renewables $^{3}$ & 20 & 23 & 36 & 61 & 74 & 82 & 4.1 \\
\hline Total & $\mathbf{3 3 9 2}$ & $\mathbf{4 3 4 2}$ & $\mathbf{4 7 3 7}$ & $\mathbf{4 8 3 5}$ & $\mathbf{5 5 3 0}$ & $\mathbf{5 1 1 0}$ & $\mathbf{1 . 5}$
\end{tabular}

${ }^{1}$ Includes the contribution of hydro, wind, photovoltaic, and geothermal power; ${ }^{2}$ includes the contribution of biogas; ${ }^{3}$ includes solar (for thermal purposes) and (low enthalpy) geothermal sources.

Source: Carlos V. Miguel, et al. ${ }^{180}$

Portugal has no indigenous oil reserves and no fossil fuel production (including coal, natural gas and oil), and thus has a high dependency on imports to produce energy. ${ }^{181}$ From 2004 to

175 See Redes Energéticas NACIONAIS, Renewable Production Supplied over $60 \%$ of Electricity Consumption in Portugal During the First Quarter of 2018 (Mar. 5, 2018), https://www.ren.pt/enGB/media/comunicados/detalhe/renewable_production_supplied_over_60_of_electricity_co nsumption_in_portugal_during_the_first_quarter_of_2018 [https://perma.cc/T3F3-D2KJ].

176 Miguel, supra note 169, at 1.

177 International Energy Agency, Energy Policies of IEA Countries: Portugal 2016 Review 38 (2016).

${ }^{178}$ Miguel, supra note 169.

179 INT'L ENERGY AGENCY, supra note 32, at 15.

180 Miguel, supra note 169at 8.

${ }^{181}$ INT'L ENERGY AGENCY, supra note 32 at 26. 
2014, energy production in Portugal rose 44.4\%. ${ }^{182}$ Energy production by renewables is steadily increasing, however its production is volatile due to the intermittent nature of the sources, leaving Portugal with the conundrum on how to the invest in and develop the urgently needed storage solutions. ${ }^{183}$

\section{i. Energy Consumption}

The country's total final consumption (TFC) was 14.9 Mtoe in 2013 per the most recent available data. ${ }^{184}$ The largest consuming sectors are industry, accounting for $36.7 \%$, and transport, accounting for $33.3 \%$ TFC. ${ }^{185}$ The residential sector represented $16.3 \%$, while the commercial and other service sectors represented 13.7\% TFC.186 From 2003 to 2013, the industrial sector cut its consumption by $26.7 \%$, transport consumption declined by $16.2 \%$, and the residential and commercial sector consumption declined by $15.3 \%$ and $3.5 \%$, respectively. ${ }^{187}$

The overall TFC increased moderately to 15.65 Mtoe in 2016.188 In 2015, the transport sector was the largest consumer, representing a $41.2 \%$ share of the country's final consumption. ${ }^{189}$ The industry sector's final energy consumption was at $27.8 \%$, the residential sector was at $15.8 \%$ and on the service sector the consumption shared $12.2 \%{ }^{190}$ The share of final energy consumption by Portugal in the transport sector was above the EU average of $33.1 \%$ while the residential sector was below the EU average of 25.4\%. ${ }^{191}$ Between 2005 and 2015, the energy consumption by the transport sector decreased by $0.8 \% .{ }^{192}$ It is

\footnotetext{
$182 I d$. at 16.

183 See generally id.

${ }^{184} \mathrm{Id}$. at 18.

185 INT'L ENERGY AGENCY, supra note 32.

${ }^{186} I d$.

${ }^{187} I d$.

188 Base de Dados Portugal Contemporâneo, Final Energy Consumption: Total and by Type of Consumer Sector, Pordata

https://www.pordata.pt/en/Europe/Final+energy+consumption+total+and+by+type+of+con sumer+sector-1397 [https://perma.cc/Y58C-U6TR] (last viewed Mar. 23, 2020) (This is an interactive website and data is toggled by year).

189 EUR. Comm’N, Energy Union Factsheet Portugal (2017).

${ }_{190} I d$.

${ }^{191} I d$.

192 Id.
} 
likely that the demand will keep decreasing due to energy efficiency initiatives and increases in renewable energy capacity and generation.

\section{ii. Energy supply}

Portugal's total primary energy supply (TPES) was 21.1 Mtoe in 2014, 18.3\% lower than 2003. ${ }^{193}$ Government projections anticipate an increase in demand in the coming years, predicting that in 2020 the TPES will be $13.5 \%$ higher than in 2014. 194 Fossil fuels account for $74.3 \%$ of TPES in 2014 (oil (45.1\%), natural gas (16.4\%) and coal (12.7\%)).195 Renewable supply, comprised of biofuels, hydroelectricity, wind, geothermal, and solar energy, accounted for $25.4 \%$ in 2014.196 The share of wind as a renewable energy increased from $0.1 \%$ to $4.9 \%$ in TPES from 2004 to $2014 .{ }^{197}$

The most recent statistics by PORTADA show that renewable energy amounted to 4,794 tonnes of oil (toe) in the TPES, an increase from the 4,141 toe in 2003, but a decline from 6,205 toe in $2016 .{ }^{198}$ The decrease of renewable energy in the TPES was mainly due to the volatility of hydropower production, exacerbated by the 2017 Iberian Peninsula drought that significantly limited hydropower energy sources.154 Portugal had also shown growing dependency on hydropower, which supplied a staggering $29 \%$ of the country's power demand between 2014 and 2016. ${ }^{199}$

Since there is a lot of potential for renewable energy development in Portugal, there should be more incentives for projects to take place, such as subsidies to help consumers install

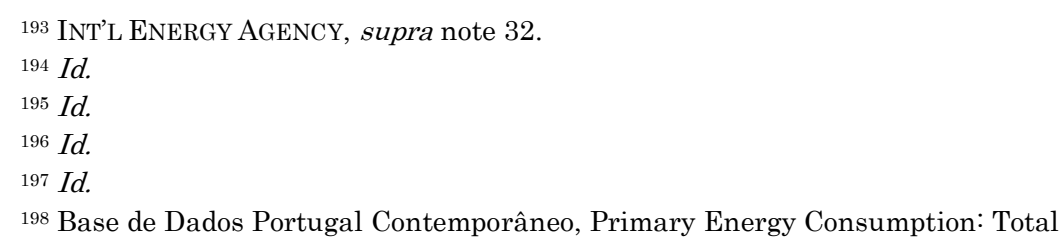
and by Type of Energy Source, Pordata,

https://www.pordata.pt/en/Portugal/Primary+energy+consumption+total+and+by+type+of +energy+source-1130-9142 [https://perma.cc/MF8M-79ZH] (last viewed Mar. 23, 2020) (This is from data on the far right of the table).

199 ICIS Power Perspective: The Iberian Peninsula Droughts - Hydro at Risk, Gas-Fired Power on the Rise, Indep. Commodity Intelligence Services (Feb. 23, 2018), https://www.icis.com/explore/resources/news/2018/02/23/10196550/icis-power-perspectivethe-iberian-peninsula-droughts-\%200xe2-0x80-hydro-at-risk-gas-fired-power-on/ [https://perma.cc/Q6P5-HWZE]. 
solar PVs in their homes. There should also be more development of storage projects, such as research and development to find the best batteries to store electricity from renewable sources.

\section{iii. Electricity generation}

Electricity generation in 2014 was 52 Terawatt-hour (TWh), 3\% higher than in 2013 and $16.1 \%$ higher than in $2004 .^{200}$ This volatility is largely the result of the variable generation by hydropower. ${ }^{201}$ In relation to electricity consumption, in 2013 it amounted to $46.3 \mathrm{TWh}$, which was $5.6 \%$ higher than in $2003 .{ }^{202}$ The energy produced in Portugal is enough to meet consumption needs, but energy is traded between Portugal and Spain. ${ }^{203}$ In 2014, imports of electricity from Spain was 0.9 TWh, accounting for $2 \%$ of domestic demand. ${ }^{204}$ These imports again varied due to the nature of hydropower generation, which ranged from 9.4 TWh in 2008 to as low as 0.9 TWh in 2014.205

The indicator of energy intensity of Portugal decreased from 152.2 toe per million of GDP in 1995 to 86.4 toe per million of GDP in 2016, however, still below EU-28 average. ${ }^{206}$ In 2010, energy consumption in Portugal peaked at 50.5 TWh, but subsequently declined in the following years, and in 2013 it was as low as 46.3 TWh. ${ }^{207}$ The largest consuming sectors are the commercial and public services sectors, which include both fisheries and agriculture, whom together consume $35.8 \%$ of electricity in Portugal. ${ }^{208}$ The demand for commercial services increased by $6.5 \%$ since 2003 . The second largest consuming sector is industry, accounting for $34.6 \%$ of electricity consumption, followed by the residential sector with $26.6 \%{ }^{209}$ The demand for industrial services decreased by $0.8 \%$ from 2003 to $2013 .^{210}$ Alternatively, consumption within the residential

\footnotetext{
200 INT'L ENERGY AGENCY, supra note 32.

201 Id.

${ }^{202} I d$.

${ }^{203} I d$.

${ }^{204} I d$.

${ }^{205} I d$.

206 Pordata, supra note 188 ("EU-28 average was 147.2 toe per million GDP in 1995 and is currently 74.2 toe per million GDP.")

${ }^{207}$ INT'L ENERGY AGENCY, supra note 32.

208 Id. at 84 .

${ }^{209} \mathrm{Id}$.

${ }^{210} \mathrm{Id}$.
} 
sector increased by $4.1 \%$ since 2003 , but decreased by $15.2 \%$ from 2010 to $2013 .{ }^{211}$ Electricity consumption in the transport sector amounts to only $0.8 \%$, as it uses mostly fossil fuels, and therefore the demand was more stable than the other sectors. ${ }^{212}$

\section{Energy Market}

\section{i. Key characteristics}

The Portuguese electricity market is on its way to being fully liberalized and privatized. This process was aided by the introduction of EU directives such as Directive 2009/72/EC ${ }^{213}$ and by measures under the financial assistance plan and conditions imposed by the Troika from 2011 to $2014 .{ }^{214} \mathrm{As}$ an EU member state, Portugal has undergone many policy changes and updates in order to liberalize and centralize its electricity market. ${ }^{215}$

In 1995, the EU released a White Paper introducing new energy policy goals, including the overall competitiveness of the electricity market, security of supply, and environmental protection. ${ }^{216}$ The policy changes meant that the liberalisation of the internal market for electricity and natural gas became a priority for all EU member states. ${ }^{217}$ Subsequently, to meet liberalisation objectives, the EU adopted the first electricity directive 96/92/EC ${ }^{218}$ and gas directive 98/30/CE, ${ }^{219}$ introducing

${ }^{211} I d$.
${ }^{212} I d$.
${ }_{213}$ Directive 2009/72/EC, of the European Parliament and of the Council of 13 July 2009 concerning common rules for the internal market in electricity and repealing Directive 2003/54/EC, 2009 O.J. (L 211) 55.

${ }^{214}$ Eurofound, Troika, EURWORK, EUROPEAN OBSERVATORY OF WORKING LIFE, (Aug. 31. 2017), https://www.eurofound.europa.eu/observatories/eurwork/industrialrelations-dictionary/troika [https://perma.cc/5SCY-LNRX]. ("The Troika is the representative of the EU in its foreign relations concerning its common foreign and security policy, specifically in relation to the International Monetary Fund (IMF), the European Central Bank (ECB), and the European Commission.").

${ }^{215}$ See, e.g., id.

${ }_{216}$ See European Commission Press Release IP/95/1418, The Commission,

Energy Policy - The Way Ahead (Dec. 19, 1995).

217 Id.

218 Directive 96/92/EC, of the European Parliament and of the Council of 19 December 1996 concerning common rules for the internal market in electricity, 1996 O.J. (L 27) 20.

${ }^{219}$ Directive 98/30/EC, of the European Parliament and of the Council of 22 June 1998 concerning common rules for the internal market in natural gas, 1998 O.J. (L 204) 1. 
competition rules and giving consumers a free choice of energy suppliers. ${ }^{220}$

Directives 2003/54/EC 221 and 2003/55/EC ${ }^{222}$ respectively replaced the previous two directives, adopting common rules for the internal electricity and natural gas markets. ${ }^{223}$ These directives, especially directive 96/92/EC, gave benefits in terms of efficiency gains, higher standards of service, price reductions and improved competitiveness. However, the directive did not adequately protect against the risks of market dominance and predatory behavior.

In Portugal, the opening of the electricity generation market transpired in 1981, however the liberalisation of large industrial consumers only happened in the mid-1990s.224 Eligibility for small consumers was extended after the market fully opened in 2004. ${ }^{225}$ However, this was only done for household consumers in 2006. ${ }^{226}$ In 2004, the EU Commission considered Portugal to be in the early stages of its competitiveness development in the electricity market.227 However, Portuguese legislation was ahead of time, due to the extension of eligibility to small electricity consumers established by Decree-Law 192/2004 of 17 August 2004. ${ }^{228}$

Decree-Laws $182 / 95$ to $187 / 95$ amended by Decree-Laws $56 / 97$ and 198/2000, established the basis of the Portuguese electricity sector. ${ }^{229}$ Additionally, Decree-laws 184/2003 and 185/2003 revised the National Electricity System (NES), adapting the Portuguese system to the Iberic Market (MIBEL). ${ }^{230}$

$$
{ }^{220} I d \text {. }
$$

${ }^{221}$ Directive 2003/54/EC, of the European Parliament and of the Council of 26 June 2003 concerning common rules for the internal market in electricity and repealing Directive 96/92/EC, 2003 O.J. (L 176) 37.

${ }_{222}$ Directive 2003/55/EC, of the European Parliament and of the Council of 26 June 2003 concerning common rules for the internal market in natural gas and repealing Directive 98/30/EC, 2003 O.J. (L 176) 57.

$$
{ }^{223} I d \text {. }
$$

${ }_{224}$ Paula Ferreira \& Madalena Araújo, An overview of the Portuguese electricity market, Univ. of Minho, 2006, at 3.

$$
{ }_{225}^{22} \text { Id. at } 4 .
$$

${ }^{226} I d$.

${ }^{227}$ EUR. ComM'N, Towards a Competitive and Regulated European Electricity and Gas Market, at 2 (2004), https://rsw.beck.de/docs/librariesprovider69/defaultdocument-library/2004/becklink-123488/08_2004_e_g_markt_en.pdf?sfvrsn=fbb8f35c_2 [https://perma.cc/9M6A-86Q5].

$$
\begin{aligned}
& { }^{228} I d \text {. at } 4 . \\
& { }^{229} \text { Ferreira, supra note } 224 . \\
& { }^{230} \text { Id. }
\end{aligned}
$$


The country's electricity model is based on two sub-systems: the public electricity system (PES) and the independent electricity system (IES), ${ }^{231}$ as illustrated in Figure 2:

Figure 2: Portuguese National Electricity System in 2004

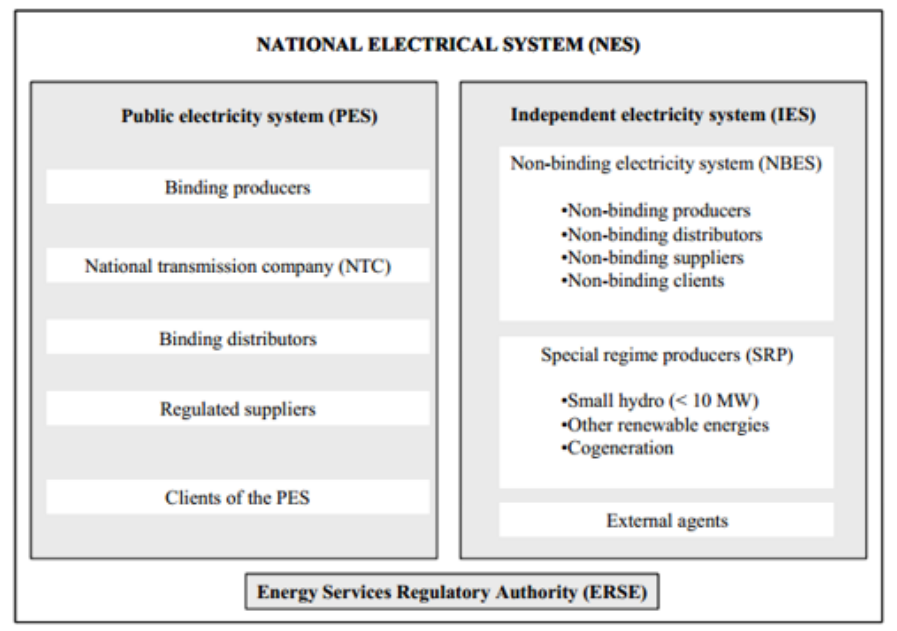

Source: $\mathrm{ERSE}^{232}$

The PES supply electricity to all mainland territory as a public service system. ${ }^{233}$ This system is comprised of production activities, national transportation grids, and distribution activities. ${ }^{234}$ Producers within this system are bonded to the National Transmission Company (NTC) with an exclusivity longterm contract and must provide exclusively through the PES. ${ }^{235} \mathrm{~A}$ concession to operate the transmission network is awarded exclusively to the NTC as a public service system. ${ }^{236}$ In Portugal, the NTC and REN are responsible for the electricity transmission. ${ }^{237}$ Medium Voltage (MV) and High Voltage (HV) distributors may only acquire electricity out of the PES with an $8 \%$ limit of their energy and power requirements and are bound

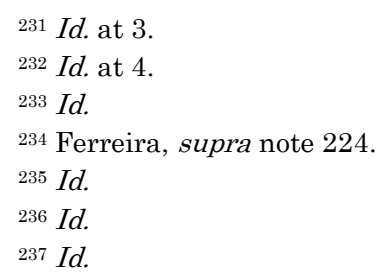


to the NTC. ${ }^{238}$ Regulated suppliers must supply to all PES clients, and as per Decree-Law 185/2003, the appointed regulated supplier (and last resource supplier) is Energias De Portugal (EDP) Distribuição. 239

The IES is formed by the non-binding electricity system (NBES) and the special regime producers (SRP). ${ }^{240}$ The NBES is set up as a non-regulated market system with availability to the production and distribution activities, excluding Low-Voltage distribution. ${ }^{241}$ The non-binding producers, distributors, suppliers and clients all form part of this system. ${ }^{242}$ For the non-binding producers and the clients to access the PES transmission and distribution grids a regulated tariff is charged for the services. ${ }^{243}$ External agents such as companies that were legally established in other EU countries that are entitled to trade electricity may participate. $^{244}$ Agents and suppliers can perform cross-border commercial transactions using the existing EU transmission grid interconnections. ${ }^{245}$

Since 2007, as per EU Directive 2003/54/EC, all member states must assure that all consumers can freely purchase electricity from the supplier of their choice. ${ }^{246}$ According to Portuguese law, all consumers located in continental Portugal have access to the NBES and can choose their suppliers and negotiate the terms of their relationship. ${ }^{247}$

The Regulatory Entity for Energy Services (ERSE) made it possible for small consumers to switch suppliers beginning in September 2006, after the implementation of necessary technology for managing the switching procedure. ${ }^{248}$ The small

\footnotetext{
${ }^{238}$ Entidade Reguladora dos Serviços Energéticos, Annual report to the European Commission, ERSE (Sept. 2005).

${ }^{239} \mathrm{Id}$.

${ }^{240}$ Ferreira, supra note 224.

${ }^{241} I d$.

${ }^{242} I d$.

${ }^{243} \mathrm{Id}$.

${ }^{244} I d$.

${ }^{245}$ Ferreira, supra note 224.

${ }^{246}$ Id. (Among other obligations, Member States must ensure the implementation of a system of third-party access to the transmission and distribution systems for all eligible customers.)

${ }^{247}$ Decree-Law No. 192/2004 of August 17, 2004 on consumers' eligibility of low voltage energy.

${ }^{248}$ Entidade Reguladora dos Serviços Energéticos, Comunicado- Consumidores domésticos podem mudar de fornecedor de electricidade a partir de Setembro de 2006, ERSE (Dec. 2005) (on file with ERSE).
} 
hydropower generation, the cogeneration, and the production from other less developed renewable energy sources all form part of the SRP regime. ${ }^{249}$ The public electric grid has an obligation to buy the electricity produced by the SRP during the license period at prices based on the avoided costs to the PES and on the environmental benefits of each of the energy sources used in production. ${ }^{250}$ The ERSE must regulate the PES and the correlation between PES and NBES. Additionally, the ERSE regulates tariffs, such as the price for electricity for final Low Voltage (LV) consumers, and adjusts rates for the services of the NTG, binding distribution companies and creating codes for commercial dealings and grid access. ${ }^{251}$

In Portugal the generation, distribution, and supply activities are unbundled, and transmission activity experienced periods of unbundling of ownership. ${ }^{252}$ There are four categories within the electricity system: the generation of electricity; the transmission of electricity through very high and high voltage grids; the distribution of electricity through high, medium and low voltage grids; and the supply of electricity to consumers. ${ }^{253}$ These different activities are mostly unbundled as will be outlined below. However, some elements of these processes are subject to regulation, such as the transmission and distribution by the supplier of last resort and the logistics operations for switching suppliers, as well as the administration of organized markets. ${ }^{254}$

Generation and supply activities are liberalized and, therefore, not regulated. ${ }^{255}$ These activities can be established by any company that follows proper procedures such as licensing, registration, or prior communication to the start of the activities. $^{256}$ There are two categories that define regimes for generation of electricity: the ordinary and the special. ${ }^{257}$ The ordinary regime includes, for example, traditional thermoelectric power plants, while the special regime covers electricity

${ }^{249} I d$.

${ }^{250} I d$.

251 Ferreira, supra note 224.

${ }^{252}$ Unbundling refers to legal and accountability separation.

253 See ERSE, Annual report on the electricity and natural gas markets in 2017: Portugal, (July 2018).

${ }_{254} I d$.

255 Ferreira, supra note 224, at 15.

${ }^{256} I d$. at 5-6.

${ }^{257}$ Pacheco and Mendes, supra note 172. 
generation from renewable sources, cogeneration, small production, and production by any other 'special' regimes, such as self-consumption. ${ }^{258}$

Portugal denationalized transmission activities in 2011, and REN controls exclusively the public concession contract for all of mainland Portugal. ${ }^{259}$ The transmissions provider by law has an obligation to connect all entities into its network on a nondiscriminatory basis if it is economically and technically feasible to do so, and if the applicant meets the connection conditions. ${ }^{260}$ The right of access to the transmission network is given by written agreement vis-à-vis the use of the network. ${ }^{261}$ The operator receives compensation for the use of its facilities as set out in the Tariff Regulation passed and monitored by ERSE. ${ }^{262}$

Under the public concession regime, operators obtain the exclusive right to perform distribution activities in different parts of the country. ${ }^{263}$ There must be an agreement drafted for the use of the distribution grids, and the payment of the regulated tariffs as established by ERSE in the Tariffs Regulation must be executed prior to access to the distribution grid. ${ }^{264}$ The regulator, the ERSE, must approve the terms and conditions of the agreement. ${ }^{265}$ Within this, there are two regimes for the supply of electricity, namely: the free market supply to eligible consumers and the supply of last resort. ${ }^{266}$

The free market supply to eligible consumers covers consumers who have been entitled to such supply since September 4, 2006. ${ }^{267}$ Such supply is provided by vendors using negotiated conditions between the parties, excluding certain conditions that are compulsory and regulations set by ERSE. ${ }^{268}$

\footnotetext{
${ }_{258} I d$.

${ }^{259}$ Decree-Law No. 228/2006 of November 22, 2006 established the privatisation process.

260 See Council of European EnERgy Regulators, Status Review on the Implementation of Transmission System Operators' Unbundling Provisions of the 3rd Energy Package (2016).

${ }^{261}$ Pacheco and Mendes, supra note 172.

${ }^{262} I d$.

${ }^{263} I d$.

${ }^{264} I d$.

$265 I d$.

266 Morais Leitão, et al., Electricity Regulation in Portugal: Overview, THOMAS REUTERS, https://www.lexology.com/library/detail.aspx?g=cfec2d65-0615-46cc-a86e76334f4f01ce\%3E. [https://perma.cc/QEC5-S7KJ], (last viewed Mar. 9, 2020).

${ }^{267} I d$.

$268 I d$.
} 
The supplier of last resort represents the supply licenses that must guarantee the universal supply to specific consumers under regulated tariffs established annually by ERSE. ${ }^{269}$ This supplier must purchase all special regime production at regulated fixed prices for each generation technology, whether under feed-intariffs or other subsidiary schemes. ${ }^{270}$ This does not mean that the special regime producers cannot sell their electricity to other suppliers. ${ }^{271}$

The generation activities in a free market regime are connected to a wholesale market, where producers can sell the generated electricity and consumers seek to buy it. ${ }^{272}$ The trading of electricity is a retail market in Portugal, where trading agents will compete to supply electricity to end customers. ${ }^{273} \mathrm{~A}$ recent trend in Portugal has been the exponential increase in renewable energy generation. ${ }^{274}$ This is such that in March 2018, the generation of electricity by renewable energy sources was superior to the effective consumption. ${ }^{275}$ Another trend is that there has been an increase in applications for production licenses. ${ }^{276}$

Portugal has also been promoting the use of electric vehicles and charging points for such vehicles that will be explored in more detail. All these activities will be discussed in the paragraphs below to determine to what extent it is aiding the country in fulfilling the intended liberalization and decentralization of the electricity market.

\section{ii. Transmission and distribution}

The national transmission grid provides electricity transmission activities under a concession agreement, awarded exclusively to REN by virtue of article 69 of Decree-Law No.

\footnotetext{
${ }^{269} I d$.

${ }^{270} I d$.

${ }^{271} I d$.

${ }^{272}$ Leitão, supra note 266.

${ }^{273} I d$.

274 See generally, e.g., Portugal produced over $100 \%$ of its electricity from renewables in March, THOMson Reuters, (Apr. 9, 2018)

https://www.weforum.org/agenda/2018/04/last-month-portugal-produced-almost-104-of-itselectricity-from-renewables [https://perma.cc/7JJ8-K3EV].

${ }^{275} I d$.

276 Pacheco and Mendes, supra note 172, at 10.
} 
29/2006 of 15 February. ${ }^{277} \mathrm{REN}$ is responsible for all transmission activities such as the planning, implementation and operation of the national transmission grids, related infrastructure, any relevant interconnections and facilities that are necessary to operate the grid. ${ }^{278}$ To ensure the efficient and homogenous operation of the system and ensure a continuous and secure supply of electricity, REN must coordinate the national electricity system's infrastructure.

For the operation of the national distribution grid an exclusive concession also needs to be granted. EDP's subsidiary, EDP Distribuição, exclusively holds the concession as per article 70 of Decree-Law 29/2006 of 5 February, as a result of a conversion of the licence held by EDP Distribuição under the previous electricity framework. ${ }^{279}$ The terms of the concession are laid out in Decree-Law 172/2006 of 23 August. ${ }^{280}$ However, in the Autonomous Region of Madeira (RAM), the concession for electricity distribution is held by Electricidade da Madeira (EDM), and in the Autonomous Region of Azores by Electricidade dos Açores (EDA). ${ }^{281}$

The electricity distribution network is approximately 99\%owned by EDP Distribuição on Portugal's mainland. ${ }^{282}$ The network consists of high-voltage (60 Kilovolts $(\mathrm{kV})$ ), mediumvoltage $(30 \mathrm{kV}, 15 \mathrm{kV}$ and $10 \mathrm{kV})$ and low-voltage overhead and underground power lines. ${ }^{283}$ Additionally, it has sub-stations, transformation posts and other equipment needed for exploitation. ${ }^{284}$ Public lighting amenities can also form part of the distribution system. ${ }^{285}$

A Quality of Service Regulation oversees the different agents and entities operating the electricity sector. ${ }^{286}$ ERSE has the responsibility to assure the fulfilment of this regulation, as per Decree-Law No. 215-B/2015 of 8 October 2015. ${ }^{287}$

\footnotetext{
${ }^{277}$ EDP - Energias de Portugal, S.A., Securities and Exchange Commission Form 20-F (Filed July 14, 2006)

${ }_{278} I d$.

279 See generally id.

280 INT’L ENERGY AGENCY, supra note 32.

${ }^{281} I$ d.

${ }^{282} I d$.

${ }^{283} I d$.

${ }^{284} I d$.

285 INT'L ENERGY AGENCY, supra note 32.

286 ERSE Regulation No. 455/2013, published 29 November 2013.

${ }^{287}$ INT'L ENERGY AGENCY, supra note 32.
} 


\section{Place in the Market for different energy sources}

Historically, Portugal has a high dependency on imported energy as it does not produce oil, natural gas, or coal. ${ }^{288}$ Recently however, an increase in renewable energy generation has led to a decline in dependency. In 2017, wind and hydro power generation were the main drivers in growing energy production in Portugal, with $21.6 \%$ wind energy and $13.3 \%$ hydropower energy production overall. ${ }^{289}$

Portugal's solar power production is expected to increase in the future, especially with new incentives and projects emerging at the national and regional levels. ${ }^{290}$ In 2017 , due to a lack of precipitation, national production decreased, and, as a result of the low representation of renewable sources, there was an increase in the annual price of electricity in the wholesale market from $€ 39.4 / \mathrm{MWh}$ in 2016 to $€ 50.40 / \mathrm{MWh}$ that year. ${ }^{291}$

Nevertheless, the country was still able to run for 122 nonconsecutive hours on $100 \%$ renewable generated electricity sources proving that running on renewable energy is achievable. ${ }^{292} \mathrm{~A}$ marked increase in renewable capacity occurred with the installation of several wind farms. New power plants have been commissioned in 2017, including the Foz Tua hydroelectric plant (263MW), the Pico Alto geothermal power plant (4.5MW), large-scale photovoltaic solar power plants (14MW), many other small-scale PV plants that count for selfconsumption, and other small projects. ${ }^{293}$ Other renewables technologies have not seen this increase in capacity, and technologies such as biomass and wind power stagnated in 2017.294

New renewable energy projects proliferated over the last few years, with many power plants licensed, and some already in

\footnotetext{
288 See, e.g., id.

289 Monica Carneiro Pacheco and João Mendes, Global Legal Insights-Energy, pp.173-181, at 173 .

290 See generally Associação Portuguesa de Energias Renováveis (APREN), Boletim Energias Eenovaveis, (Sep. 2017).

291 Id.

292 Peter Dockrill, Portugal Just Ran For 4 Straight Days Entirely on Renewable Energy, (2016) https://www.sciencealert.com/portugal-just-ran-for-4-straight-daysentirely-on-renewable-energy [https://perma.cc/6SZQ-DBYA].

${ }^{293}$ Mendes, supra note 289, at 174.

${ }^{294} I d$. at $173-81$.
} 
the construction stage. The Portuguese Government predicts that by 2021, the current installed capacity of renewable energy sources will increase from a total of 572MW to 1,600 MW, counting with the 30 power plants currently being built. ${ }^{295}$ Power purchase agreements are being negotiated with energy traders and suppliers, pursuant to the generator responsible for enabling the disposal of the electricity for a buyer, who in turn will resell it on organized retail markets or by bilateral agreements. ${ }^{296}$ This method gives generators a price per MWh agreed with the buyers. ${ }^{297}$ This represents an effective change in policy from the previous remuneration method for renewable projects through feed-in-tariffs set by law and regulation, which have not increased as predicted. ${ }^{298}$

For the promotion of renewable energy to be fruitful, the intermittency and storage conundrum must be addressed. This is one of the reasons Portugal is witnessing a 'lithium rush', with growing utilization of the mineral to produce batteries used in electric vehicles and electricity storage. 299

The country has also been encouraging development and investment in electro-mobility, as discussed in section 1.6. of this article. Portugal has territory that forms part of the EU outermost regions (ORs), with a high potential for renewable energy sources to be used instead of fossil fuels, due to the regions having ideal weather conditions such as all-year round sunlight. ${ }^{300}$ Included in these small islands is the island of Porto Santo in RAM. ${ }^{301}$ This island is a perfect candidate to become a self-sufficient community based on renewable energy sources, and could be a leader in the low-carbon transition. ${ }^{302}$ The problem is the isolation of the island can make it difficult to obtain energy sources if renewable energy sources fail to operate leading to a

295 See Portugal to triple solar capacity by 2021, InSTITUTE FOR ENERGY ECONOMICS \& FINANCIAL ANALYSIS (July 27, 2018), [https://perma.cc/W544-4JAE].

296 See Mendes, supra note 289, at 173-81.

${ }^{297} \mathrm{Id}$.

$298 \mathrm{Id}$.

${ }^{299}$ See Thomas Cabral, Booming electric car sales drive lithium rush in

Portugal, PHYs ORG (Sept. 13, 2018), https://phys.org/news/2018-09-booming-electric-carsales-lithium.html.

300 See generally Eduardo Maldonado, "Final Report: Energy in the EU Outermost Regions (Renewable Energy, Energy Efficiency)", 1-21, at 2.

${ }^{301} I d$. (Explaining how small Islands (with the exception of French Guiana) which have a vast supply of renewable energy sources that are better than in continental Europe but are still heavily dependent on oil imports.)

${ }^{302} I d$. 
potential shortage. This makes it crucial to have guarantees of system stability and penetration of storage solutions.

The Portuguese government saw the potential of Porto Santo Island and has started a pilot project to develop storage capacity to use more effective stability providers, such as better batteries, ${ }^{303}$ and has plans to increase the renewable capacity of the island. ${ }^{304}$ Porto Santo plans to be $100 \%$ renewable by 2030 and the island's favourable weather conditions are an advantage in achieving this objective. ${ }^{305}$ However, the island lacks the necessary infrastructure needed to fully capitalize on intermittent energy sources, and more investment and initiative may be needed to achieve these objectives. ${ }^{306}$ For example, instead of investing in the current infrastructure used to produce energy in the island from gas and oil, the investment should be going to replacing wind turbines that were removed.

\section{E. The liberalization of the Portuguese electricity market}

The liberalization of the electricity market in Portugal mirrored that of most EU member states. ${ }^{307}$ The process started with the entrance of independent power producers with long-term contracts. ${ }^{308}$ Following this, a more active wholesale market was established, and finally, a retail market opened to competition at the last stage. ${ }^{309}$

Different legislation has been introduced in Portugal to aid the process. ${ }^{310}$ In 1981, Decree-Law 20/81 mentioned for the first time the possibility of electricity auto-production, for entities producing from renewable energy or using technology that

\footnotetext{
303 See id.

304 See Pact of Islands, Sustainable Energy Action Plan: Porto Santo Island (Mar. 2012), http://aream.pt/files/2016/05/ISEAP_Porto_Santo_EN.pdf [https://perma.cc/4PX9-PDKV].

305 See Maldonado, supra note 300 , at 3.

306 Andrei Khalip and Sergio Goncalves, Exclusive: Portugal to launch tender of lithium exploration licenses this year, REUTERS (Sept. 25, 2018 6:05 AM), https://www.reuters.com/article/us-portugal-lithium-exclusive/exclusive-portugal-tolaunch-tender-of-lithium-exploration-licenses-this-year-idUSKCN1M5199 [https://perma.cc/UF9K-9N63].

${ }^{307}$ Ferreira, supra note 224.

308 Id.

${ }^{309}$ A. Al-Sunaidy \& Richard J. Green, Electricity deregulation in OECD countries, Energy, (2006) vol. 31 (6-7), 769-87.

${ }^{310}$ Ferreira, supra note 224.
} 
promoted reduction in primary energy consumption. ${ }^{311}$ DecreeLaw 149/86 of 1986 built on the principle onto power plants that exclusively produced electricity. ${ }^{312}$ There were delays, however, which led to the introduction of Decree-Law 189/88 to establish a more rapid liberalization procedure and created conditions allowing for the economic viability for small power plants. ${ }^{313}$ Decree-Law 189/88 replaced the previous laws and instituted guidelines for independent power production, which allowed and incentivized the production of electricity from renewable energy sources and co-generation. ${ }^{314}$

Decree-Law 99/91 introduced the PES, along with the license system that fully opened competition in the electricity generation sector. ${ }^{315}$ Following this, Decree-Laws 182/95 to 187/95 revised Decree-Law 99/91, setting the bases of the PES and the IES in 1995.316 The process was followed by the progressive opening of the retail market between 1995 and 2004.317

The Portuguese wholesale market is jointly established with Spain's. ${ }^{318}$ The Portuguese and Spanish governments signed an agreement to develop the Iberian power market (MIBEL) in 2004, approved by the Resolution of the Assembly of Republic 33A/2004. ${ }^{319}$ Decree-Laws 184/2003 and 185/2003 established the dispositions for the supply, importation, and exportation activities in the free Iberian market, where electricity is traded by bilateral contracts or on organized markets and the Power Purchase Agreement will be terminated. ${ }^{320}$ Any termination of these agreements triggers economical compensations to the involved parties. In Decree-Law 240/2004, values for maximum compensation for the PES power plants were established. ${ }^{321}$

\footnotetext{
${ }^{311} I d$.

$312 I d$.

${ }^{313} I d$. (Since its publication, Decree-Law 189/88 suffered some changes published in subsequent text laws.)

${ }^{314} \mathrm{Id}$.

315 Ferreira, supra note 224.

${ }^{316}$ Id. (Since its publication, Decree-Law 182/95 suffered some changes

published in subsequent Decrees-Law.)

${ }^{317} \mathrm{Id}$.

${ }^{318} I d$.

$319 I d$.

${ }^{320} I d$.

${ }^{321}$ Ferreira, supra note 224. (The European Commission has examined the state aid given to EDP in relation to the compensation).
} 
Figure 3: The Process of Liberalization of the Portuguese Electricity Market

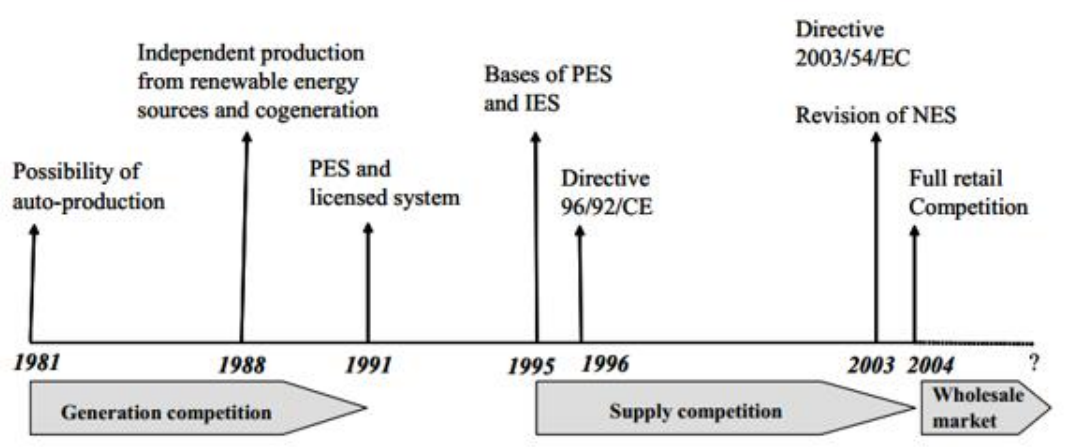

Source: Paula Ferreira and Madalena Araújo, An overview of the Portuguese electricity market, (2006) Paper from the Department of Production and Systems, University of Minho, pp.1-19, p.5.

The electricity-market liberalization process in Portugal, as depicted in Figure 3, was meant to make the electricity market competitive and result in more favorable tariffs for consumers. ${ }^{322}$ In 2012, the Portuguese government announced the elimination of regulated tariffs, which was meant to resolve the electricity tariff deficit and the elimination of regulated for domestic consumers finalising the liberalisation process of the electricity market in the country. ${ }^{323}$ Under the terms of Government Ordinance No. 39/2017 of January 26, 2017, consumers who still have regulated tariffs have a transitional period until December 31,2020 , to choose an electricity market supplier. ${ }^{324}$

Government Ordinance No. 144/2017 of April 24, 2017, states that consumers who still have these regulated tariffs have a transitional period until December 31, 2020, to choose a natural gas market supplier. ${ }^{325}$ It is free to switch suppliers in Portugal, a process that is propelled by the supplier where the consumer has chosen for the supply of electricity and it requires no changes of

\footnotetext{
322 See generally id.

${ }^{323}$ EUR. ComM'N, Country Reports: Portugal (2014).

${ }^{324}$ Government Ordinance No. 144/2017 (April 24, 2017).

${ }^{325} I d$.
} 
meter. ${ }^{326}$ ERSE provides lists of companies that operate in the electricity market and offers a price comparison simulator to help consumers be better informed before switching supplier. ${ }^{327}$

\section{F. Regulatory Framework}

\section{i. Regulators}

As already mentioned, the generation and supply of electricity and natural gas in Portugal are free activities, which are not regulated. On the other hand, the operation, transmission and distribution, LNG terminals and storage facilities, as well as maintenance and exploration activities are regulated, with access tariffs that are administered by the national regulatory authority, ERSE. ${ }^{328}$ ERSE is responsible for the regulation, supervision and sanctioning of the energy sector. ${ }^{329}$ Law No. 9/2013 of January 28, 2013, created the Energy Sector Sanctioning Regime and reinforced ERSE's sanctioning competencies and functions. ${ }^{330}$ Decree-Law No. 84/2013 of June 25 revised ERSE's by-laws and completed the implementation of Directives 2009/72/EC and 2009/73/EC. ${ }^{331}$

Another regulatory body worth mentioning is the General Directorate of Energy and Geology (DGEG), which develops and implements state policies and guidelines concerning the energy sector and the exploitation of natural resources. ${ }^{332}$ The DGEG responsibilities include licensing and other clerical permissions that are energy related, such as exploration and production licenses for oil and gas developments, or power-generating

326 See generally id.

${ }^{327}$ ERSE, Compare os preços das ofertas comerciais de eletricidade e gás natural, https://simulador.precos.erse.pt/ [https://perma.cc/FK65-UY82] (last viewed Oct. $5,2020)$.

${ }^{328}$ Bruno Azevedo Rodrigues \& Ashick Hussein Remetula, The Energy and

Markets Review 9th ed., The LAW Reviews (July 2020); See also Decree-Law No.97/2002 of April 12, amended by Decree-Law No.212/2012 of September 25. (ERSE's by-laws were enacted by Decree-Law No.97/2002 of April 12, 2002, amended by Decree-Law No.212/2012 of September 2012).

329 See generally id.

330 See generally id.

331 See generally id.

332 Rodrigues, supra note 328; see also DIRECANO-GERAL DE ENERGIA E Geologia, Republica Portuguesa, DGEG,

http://www.dgeg.gov.pt/?cn=7165726772697295AAAAAAAA [https://perma.cc/8K5K-5LJ9] (last viewed Mar. 24, 2020). 
licenses. ${ }^{333}$ In this respect, ERSE is the independent national regulatory authority, and the DGEG represents the state on energy matters, with licensing matters. ${ }^{334}$

The main legal framework for the electricity sector can be found in Decree-Laws No. 29/2006 and No. 172/2006, both created on February 15, 2006. ${ }^{335}$ The governing laws for the natural gas sector can be found in Decree-Laws No. 30/2006 of 15 February 2006, and No. 140/2006 of 26 July. ${ }^{336}$ The regulations put forward by ERSE, such as the Commercial Relations Regulations, the Tariff Regulations, the Quality of Service Regulation and the Infrastructure Operation Regulation are also sources of law within the scope of the energy sector. ${ }^{337}$ The DGEG also has put forward regulations, namely the Transmission Network Regulation and the Distribution Network Regulation. ${ }^{338}$

Government policies have been set up in the National Plan of Action for Energy Efficiency 2013-2016 (PNAEE 2016) ${ }^{339}$ and in the National Plan of Action for Renewable Energies 2013-2020 (PNAER 2020). ${ }^{340}$ These two policies were designed to aid the improvement of strategic energy creation and use by finding ways to achieve international goals and obligations Portugal has committed to, such as the goal to reduce energy consumption by twenty-five percent by 2020. ${ }^{341}$ Considering the country's dependence on imports of fossil fuel resources, and the economic situation in the previous decade, these Plans of Action aim to reduce energy dependence by increasing renewable source generation and promoting energy efficiency, assuring an increasingly sustainable future. ${ }^{342}$

${ }^{333} I d$.

${ }^{334}$ Id.

${ }_{335}$ See InT'L ENERgy AGENCY, supra note 32.

${ }_{336}$ See id.

${ }^{337}$ Ferreira, supra note 224.

338 Pacheco and Mendes, supra note 172.

${ }^{339}$ Leitão, supra note 266.

${ }^{340} I d$.

341 Jose L. Sousa \& Antonio G. Martins, Portuguese Plan for Promoting Efficiency of Electricity End-Use: Policy, Methodology, and Consumer Participation, 11 MDPI ENERGIES 1, 3 (2018).

$$
{ }^{342} I d \text {. }
$$




\section{ii. Regulated activities}

The transmission and distribution of electricity are subject to administrative authorizations, in most cases given by the General Directorate for Energy and Geology (DGEG). ${ }^{343}$ The operation and exploration of the national transmission and distribution networks are given under concession agreements entered with the government, which grant the exclusive right to explore the networks within an agreed region with the concessionaires for 50 years for transmission and 35 years for distribution activities. ${ }^{344}$ In addition to the national distribution network (generally high and medium voltage), there are municipal distribution networks, mainly low-voltage grids. ${ }^{345}$ The right of exploration of the municipal grids is granted by concession agreements given by the corresponding municipalities for a period of 20 years. ${ }^{346}$

The exploration, production, transmission, distribution, and operation of liquid natural gas (LNG) terminals and LNG storage facilities are regulated subject to administrative authorisation. ${ }^{347}$ The operation of LNG transmission and distribution networks and of LNG storage facilities are granted by means of concession that last 40 years within a certain area. ${ }^{348}$ Additionally, there are local natural gas distribution networks, without physical connection to the national distribution network. ${ }^{349}$ A 20-year license is obtained for the operation from the Minister of the Economy and Employment (MEE) and delivered to the DGEG's office. ${ }^{350}$

\footnotetext{
${ }^{343}$ Leitão, supra note 266.

${ }^{344} \mathrm{Id}$.

345 See generally Mónica Carneiro Pacheco \& Bernardo Cunha Ferreira, Oil and Gas Regulation in Portugal: Overview, Thomas ReuTERs, https://uk.practicallaw.thomsonreuters.com/w-0178901?transitionType $=$ Default\&contextData $=($ sc. Default $) \&$ firstPage $=$ true [https://perma.cc/RAF2-FZ6W] (last viewed Mar. 9, 2020) (explaining oil and gas regulation in Portugal).

${ }_{346} I d$.

${ }^{347} I d$.

$348 I d$.

${ }^{349} I d$.

350 Regulatory COMmission FOR the SAFETy OF NUClEAR Installations, Seventh National Report by Portugal, CONVEnTION ON NuCleAR SAFETy (Aug. 2016), iaea.org/sites/default/files/portugal-seventh-national-report.pdf [https://perma.cc/GV7PW9NU].
} 
Regarding the right for oil exploration, development and production is granted by the MEE also through a concession agreement. ${ }^{351}$ No discovery of oil that would be economically viable to explore and produce has ever been found in Portugal. ${ }^{352}$ However, the law was established in a way that makes it an attractive and simple endeavour for upstream activities. For example, there is no legal obligation for production sharing and the concessionaire is exempt from paying royalties and free to sell the oil, except in the event of a war or national emergency. ${ }^{353}$ The concessionaire is free to dispose of any natural gas found and does not have to pay any production tax. ${ }^{354}$ These concession agreements are granted by means of a public procurement process. ${ }^{355}$

The generation of electricity is a free activity, subject to the granting of a generation license. ${ }^{356}$ The licensing entity can vary, depending on the technology used or the location of the generation plant.357 Prior the industrial exploration, the generation entity must obtain an exploration license, which is granted after technical inspections take place to ensure the safety conditions of the operating plant. ${ }^{358}$

\section{G. Smart metering systems}

Smart metering systems are crucial in the energy sector as they will allow collection of detailed data on the energy use of small consumers. ${ }^{359}$ Portugal has undertaken various studies and field trials of smart metering technology. ${ }^{360}$ The information obtained from the studies should be utilized to support the rollout of advanced metering technologies to smart meter systems and commercial enterprises with a view to supporting their efforts to manage energy demand. ${ }^{361}$ Infrastructure and

\footnotetext{
${ }^{351}$ See generally id.

${ }^{352}$ See generally id.

${ }^{353}$ Pacheco \& Ferreira, supra note 345.

${ }^{354} I d$.

$355 \mathrm{Id}$.

${ }^{356} I d$.

${ }^{357}$ Pacheco \& Ferreira, supra note 345.

${ }_{358} I d$.

${ }^{359} \mathrm{Id}$.

${ }_{360} I d$.

${ }^{361} I d$.
} 
regulatory incentives are not heavily present in the country for this type of technology, but there is evidence that it is emerging.

There are a few examples of pilot projects taking place to test and roll-out smart metering systems. For example, a project called SmartGalp (2010-12) was a technical study in the smart metering sector aiming to demonstrate and quantify the bundling that the real-time consumption monitoring and new interactions with residential consumers could have on: energy efficiency, consumption reduction, greenhouse gas (GHG) emissions, and in cost reductions for the end-consumer. ${ }^{362}$ Other projects have been implemented such as Your Home, Your Energy (PPEC) (2014-15), a nationwide initiative focusing on the promotion of energy efficiency in the residential sector, with the aim to contribute toward an effective reduction on energy consumption. ${ }^{363}$ This project provided access to information regarding energy efficiency measures, tailored to individual consumers depending on their energy spending. ${ }^{364}$ The information for the tailored plans was provided through measures such as smart metering data. ${ }^{365}$

According to the International Energy Agency's 2016 report, EDP Distribuição is developing second-generation of smart meters for 100,000 customers throughout Portugal, aiming to develop a supply chain and improve the integration of existing processes. ${ }^{366}$ However, Portugal still has no legal framework for wide-scale smart meter development that can provide a challenge to the development of the technology, as regulatory uncertainty generally stagnates progress. ${ }^{367}$

\section{H. Electric mobility}

Portugal is committed to improving mobility by introducing more electric vehicles and improving charging infrastructure. There has been an expansion of the national public grid in the form of charging stations and installations of

\footnotetext{
$362 I d$.

363 Int'L Energy Agency, Energy Policies of IEA Countries: Portugal, 137 (2016).

${ }^{364} I d$.

$365 I d$.

${ }^{366} I d$. at 57 .

367 See generally id. (encouraging member states to create frameworks to market energy services and energy efficient programs).
} 
charging infrastructures at home and in the workplace. ${ }^{368}$ In some regions, such as the RAM, a project called Sustainable Porto Santo/Smart Fossil Free Island is experimenting on electric mobility and vehicle-to-grid (V2G) technology, which is detailed in this article. ${ }^{369}$

There are free charging points for volunteers of a Renault electric vehicle project to use for 18 months on the island. ${ }^{370}$ The project is a cooperation between the car company Renault and Empresa de Electricidade da Madeira (EEM), costing €9 million in the first phase to install 40 charging points for 14 Renault Zoe cars and six Kangoo electric vans. ${ }^{371}$ This pilot scheme is serving as a "testing ground" for the future of electric mobility and electric storage in other countries in Europe after Porto Santo. ${ }^{372}$ The pilot scheme will help advance electric vehicle solutions technologically and economically, and show how decentralized grids can be an effective and achievable solution to reduce infrastructure costs and encourage the consumption of renewable energy.

Portugal wants to increase competition in electric vehicles and reduce the price difference of electric and plug-in hybrid vehicles compared to conventional vehicles. ${ }^{373}$ It is achieving this through the introduction of the Green Taxation Reform that provides government incentives for subsidising schemes that help the public and public administration acquire electric vehicles. ${ }^{374}$

The Portuguese government, as an attempt to drive independence on conventional resources for the production of energy, and due to the environmental impacts of the use of fossil fuels, has invested in various newly founded energy models for mobility to reduce air pollution and increase quality of life. ${ }^{375}$

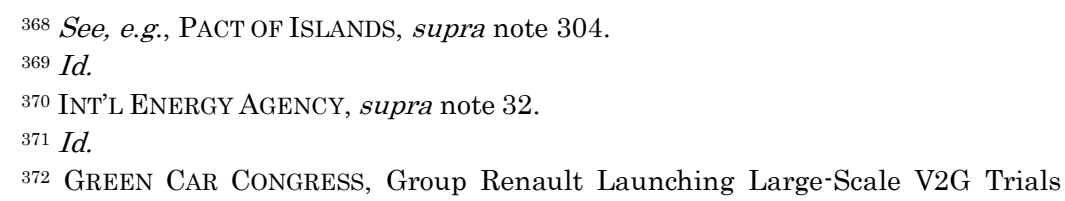
With Fleet of 15 Zoe EVs (Mar. 22, 2019),

https://www.greencarcongress.com/2019/03/groupe-renault-launching-large-scale-v2gtrials-with-fleet-of-15-zoe-evs.html [https://perma.cc/QT7H-2HJ2].

${ }^{373}$ See generally Mobi.E: The Portuguese Programme for Electric Mobility, ELTIS (Sept. 2, 2014), https://www.eltis.org/discover/case-studies/mobie-portuguese-programmeelectric-mobility [https://perma.cc/6UKQ-RZ6C].

374 See id. ("The Portuguese government created the Commission for the Green Tax Reform in 2014, following the guidelines of the European Union in the sense that fiscal policy should contribute to public budget consolidation and sustainable growth.")

375 See generally id. 
This has led to the creation of the Electric Mobility Network, a MOBI.E-managed integrated networking that links 1,300 charging stations in Portugal, enabling electric vehicles to recharge their batteries by using a charging card. ${ }^{376}$ This network introduced a sustainable mobility prototype, which integrated electric vehicles into the market and promoted the benefits of electricity created and used from renewable energy sources. ${ }^{377}$

Additionally, in March 2010, a project was initiated for the extensive implementation of the Electric Smart Grid led by EDP Distribuição SA. ${ }^{378}$ The first stage was the implementation of the project, where 30,000 electric power metres (otherwise called 'energy boxes') were installed in the city of Évora. ${ }^{379}$ The project promoted electric mobility, as well as microgeneration and energy efficiency. ${ }^{380}$ This is an innovative project, as consumers have new services, new charging systems and more beneficial rate plans, which allows greater freedom of choice and increases competitiveness. ${ }^{381}$ Consumers can also adjust the services to match their consumption needs, and enjoy a speedy, transparent and convenient new services system. ${ }^{382}$

Lastly, there are financial incentives for consumers to acquire electric vehicles. The government approved incentives totalling $€ 2,659,000$ in 2018 through the Environmental Ministry in context of the Environmental Fund created in $2016 .{ }^{383}$ Other tax incentives include exemptions from taxes being paid on the acquisition of the vehicle, and a reduction in circulation tax. ${ }^{384} \mathrm{In}$ addition, businesses benefit from a reduction in value added tax. $^{385}$ Finally, under Decree-Law no. 140/2010 of December 29,

\footnotetext{
${ }^{376} I d$.

377 See Mobilidade Electrica,Why Choose Electric Mobility?, MOBI.E, https://www.mobie.pt/why-electric-mobility [https://perma.cc/P4YX-GHG2] (last viewed Oct. 16, 2020).

378 EDP DISTRIBUIÇÃO, Évora Inovcity, https://www.edpdistribuicao.pt/en/evorainovcity [https://perma.cc/TR7F-ARN3] (last viewed Mar. 20, 2020).

${ }^{379} \mathrm{Id}$.

${ }^{380} \mathrm{Id}$.

${ }^{381} I d$.

${ }^{382} I d$.

${ }^{383}$ Mónica Carneiro Pacheco \& Bernardo Cunha Ferreira, CMS Expert Guide to Electric Vehicles: Portugal, CMS L. (Aug. 2, 2018), https://cms.law/en/int/expertguides/cms-expert-guide-to-electric-vehicles/portugal [https://perma.cc/DV6A-SWSC].

${ }^{384} \mathrm{Id}$.

${ }^{385} I d$.
} 
the Portuguese Government promoted the obligation on public and government entities to acquire electric vehicles. ${ }^{386}$

\section{Demand response}

The implementation and execution of demand response (DR) programs is becoming more important worldwide in energy markets. ${ }^{387}$ In an analysis throughout Europe of demand response systems, the Smart Energy Demand Coalition ${ }^{388}$ emphasised that the only demand response services promulgated in Portugal were interruptibility contracts. ${ }^{389}$ These contracts are only available to consumers with a contracted power above $4 \mathrm{MW}$, such as large industrial customers, with varying availability and use payments. ${ }^{390}$ These seem to be viewed as an add-on solution for emergencies rather than the primary choice for when emergencies happen, as system operators have failed to activate the contracts in the many years that they have been available. The exclusion of small-scale consumers, such as residential and small-commercial customers, may be said to hinder progress in developing DR programs in the country.

Additionally, Ministerial Order No. 41/2017 introduced a new method of remuneration for energy generators that provide security services in times of need, and also set up a scheme for Capacity Payments. ${ }^{391}$ Participation in the scheme occurs when the market players that provide power capacity in critical periods use electricity generation units or operate through DR

386 Id.

387 Explicit Demand Response in Europe: Mapping The Markets of 2017, SMART ENERGY DEMAND COAL. 1, 7 (2017), https://www.smarten.eu/wpcontent/uploads/2017/04/SEDC-Explicit-Demand-Response-in-Europe-Mapping-theMarkets-2017.pdf [https://perma.cc/2AGD-B8VM].

388 See generally id. (explaining Smart Energy Demand Coalition analysing explicit demand response in Europe for the year 2017).

389 FACTBOX - Britain's interruptible gas contracts, THOMSON REUTERS (Jan. 8, 2010), https://uk.reuters.com/article/uk-britain-gas-supply-factbox/factbox-britainsinterruptible-gas-contracts-idUKTRE60742520100108 [https://perma.cc/BQK5-JT5B].

390 Jessica Stromback, Explicit Demand Response in Europe: Mapping the Markets 2017, SMART EnERGy DEmand CoAlition, (Apr. 6, 2017), https://www.smarten.eu/wp-content/uploads/2017/04/SEDC-Explicit-Demand-Response-inEurope-Mapping-the-Markets-2017.pdf [https://perma.cc/NAM5-EWZF].

391 Capacity Payments, REDEs ELÉTRICAS NACIONAIS, http://www.mercado.ren.pt/EN/Electr/ActivitiesServices/CapacityPayments/Pages/default. aspx [https://perma.cc/2P3D-55DR] (last viewed Mar. 20, 2020). 
programs. ${ }^{392}$ But there is a limit to the participation of DR programs, as the Ministerial Order imposes a high minimum aggregation threshold of 10MW. ${ }^{393}$

Even though there are some obstacles and a lack of regulatory incentives, new DR program opportunities have are arising due to the promotion and introduction of renewable energy sources. The increased focus on renewable energy is apparent by the surge in wind power from $168 \mathrm{GWh}$ in 2000 to $11,608 \mathrm{GWh}$ in 2015 , reaching a total share of $24.7 \%$ of the power supplied. ${ }^{394}$ As the country has a high level of renewable energy generation, which is intermittent and unpredictable, reinforces the need to enable and promote DR systems.

Portugal enjoys active customer participation in the retail electricity market, as seen by the $21 \%$ of households switching rate for their electricity supplier in 2016, the highest in Europe. ${ }^{395}$ Some trial projects related to DR programs started to complement the introduction of renewable energy, but also worked to build on automated DR technologies. ${ }^{396}$ Some of these DR pilot projects will be outlined to demonstrate the position that the country currently stands.

i. Control of heating, ventilation and air conditioning (HVAC) systems in public buildings

There was a demonstration project started between the Portuguese National Laboratory for Energy and Geology (LNEG) and the New Energy and Industrial Technology Development Organisation (NEDO) in order to improve computerized DR technology and balance out supply and demand at the Lisbon City Hall and other urban amenities in the capital. ${ }^{397}$ The

392 Portaria No. 41/2017, de 27 de Janeiro 2017, Diario da Republica [D.R.], Series 1, No. 20 (Port.).

393 See generally id.

${ }^{394}$ Council of EuR. Energy Reg., Retail Markets Monitoring Report, Ref. No. C17-MMR-83-02 (2017).

395 Id.

396 See generally id.

${ }^{397}$ NEDO Launches a Demonstration on Automated Demand Response

Technology in Portugal: Aiming for the Stabilization of Power Supply and Demand Associated with the Mass Introduction of Renewable Energy, New ENERGY \& INDUs. TECH. DEv. ORG. (Nov. 22, 2016),

https://www.nedo.go.jp/english/news/AA5en_100135.html [https://perma.cc/B4SM-3EWK]. 
project's development had a three-year time period between 2016 and 2019.398

The involved parties were the innovation department from EDP Inovação, together with an IT consulting and outsourcing solution company called Everis, a provider of engineering solutions, a company specializing in control and management of electricity grids, called Efacec Energia, and a Japanese air conditioning supplier named Daikin Industries. ${ }^{399}$

This project's purpose was to remotely control the varying cooling capacity in air conditioners that have a cold air storage operation and enable the altering of output based on renewable supply and demand. ${ }^{400}$ This includes a module that forecasts weather conditions a day ahead as well as usage patterns. ${ }^{401}$ The system will then remotely and automatically adjust electricity consumption based on the data collected. ${ }^{402}$ The information collected will also go to a virtual power plant (VPP) that is used by a group of energy retailers to bid on electricity supply from renewable energy sources. ${ }^{403}$

Another project called NetEffiCity ${ }^{404}$ implemented a consumer-to-consumer electricity sharing system in Portugal. ${ }^{405}$ The parties involved in the project are a technology company with expertise on energy savings and efficiency, Virtual Power Solutions (VPS), together with a research group within the

$$
\begin{aligned}
& { }^{398} I d \text {. } \\
& { }^{399} I d \text {. } \\
& { }^{400} I d \text {. } \\
& { }^{401} \text { See generally id. } \\
& { }^{402} \text { NEDO and Daikin Develop and Install Automated Demand Response }
\end{aligned}
$$

Demonstration System in Portugal: Operation Starts in July, New ENERGy \& INDus. TECH. DEV. ORG. (Jun. 28, 2016), https://www.nedo.go.jp/english/news/AA5en_100388.html [https://perma.cc/MXQ9-3FA3].

403 Daikin Selected for Automated Demand Response Project in Portugal:

Helping to Stabilize Supply and Demand or Large-Scale Renewable Energy, DAIKIN (Nov. 22, 2016), https://www.daikin.com/press/2016/161122/press_20161122.pdf

[https://perma.cc/DHN5-96L3].; See also, Automated Demand Response Technology in Portugal: Automation Business Unit from Efacec Announces, with Great Pleasure, its Participation in a New Project that Involves R\&D Laboratories, Government Institutions and Industry Companies from Japan and Portugal, efacec.pt (Dec. 15, 2016), https://www.efacec.pt/en/automated-demand-response-technology-in-portugal/ [https://perma.cc/9XT5-S9X8].

${ }^{404}$ NetEffiCity, Compete 2020.gov.pt (Dec. 16, 2016), https://www.compete2020.gov.pt/noticias/detalhe/Proj18015_NetEffiCity. [https://perma.cc/MF5A-25ZJ].

${ }^{405}$ Lurian Klein, et al., Community $S:$ An Energy Sharing Approach Towards Energy Systems, 3 InT. CONF. ON ENERGy \& EnV.: BRINGING TOGETHER ENGINEERING \& ECON. 697-703 (2017). 
Institute of Engineering at the Polytechnic of Porto, the GECAD (Research Group on Intelligent Engineering and Computing for Advanced Innovation and Development), and a Portuguese energy supplier, Simples Energia. ${ }^{406}$

The project was in trial until mid-2018 in two Portuguese municipalities, Alfândega da Fé and Penela.407 The main objective was to show that peer-to-peer energy sharing was a feasible business model, however the project also intended to develop an automated DR program for remote and automated control of HVAC systems. ${ }^{408}$ It proposed to use automatic DR models that optimize attainment of electricity in the energy market, taking into consideration the supply from newly developed renewable sources, such as Photovoltaic cells, and flexibility from participant public buildings. ${ }^{409}$ The financing of this project was obtained through the Portugal 2020 program under COMPETE 2020 and the EU under the European Regional Development Fund. ${ }^{410}$

\section{ii. Control of HVAC loads in banks}

An Energy Performance Contract was entered into between VPS and a Spanish bank that operates in Portugal. ${ }^{411}$ VPS installed an Active Energy Management System, called Kisense, in 100 bank branches across the country. ${ }^{412}$ There are constraints due to the deregulation on DR, however Kisense can perform DR programs in allocated buildings, providing flexibility in services as part of the energy contracts, and promote microgrids in liberalized energy markets. ${ }^{413}$ One example is that the platform provides optimized aggregated energy management, load shedding, and load shifting of HVAC systems. ${ }^{414}$ Due to this platform, the average annual energy cost reduction in 2017 was

${ }^{406} I d$.

${ }^{407} I d$.

${ }^{408} I d$.

${ }^{409} I d$.

${ }^{410}$ EUR'N COMMISsION, Competitiveness and Internationalisation OP, https://ec.europa.eu/regional_policy/en/atlas/programmes/2014-

2020/portugal/2014pt16m3op001 [https://perma.cc/G7SX-AWYV] (last viewed Mar. 10, 2020).

\footnotetext{
411 See Klein, supra note 405.

${ }_{412} \mathrm{Id}$.

${ }^{413} I d$.

${ }^{414}$ Id.
} 
of $17 \%$ by the correspondent bank branches. ${ }^{415}$ Systems like these can capitalize on flexibility of peak demand and minimize unnecessary electricity usage. ${ }^{416} \mathrm{DR}$ systems can reduce the price of electricity.

\section{iii. Control of Industrial Loads}

The Galp Energy Manager was a project in Portugal associated with DR that aimed to improve DR systems and energy efficiency in more than 150 small and medium sized sectors in Portugal. ${ }^{417}$ The development was coordinated by VPS in partnership with Galp Energia. ${ }^{418}$ The participating industries identified at least one flexible load to be managed by Kisense, allowing VPS to implement the promotion of load shifting and shedding on loads of small-to-medium proportions (between 10 and $200 \mathrm{KW}$ ), and was created on the assessment of energy tariffs and peak hours of supply and demand. ${ }^{419}$ This was done through automated DR programs, or manually through remote assistance by an energy manager from VPS. ${ }^{420}$

\section{iv. EDP Distribuição pilots}

EDP Distribuição is the main Portuguese Distribution System Operator (DSO) with a large share of the energy market. ${ }^{421}$ The DSO is managing a demonstration project called InovGrid, a project that implemented a large-scale smart grid in the city of Évora. ${ }^{422}$ The city was the first in the region to have smart metering infrastructure, with around 35,000 smart meters and 340 distribution transformer controllers. ${ }^{423}$ Regarding DR,

${ }^{415}$ See generally id.

${ }_{416} I d$.

${ }^{417}$ Salla Annala, et. al., Comparison of Opportunities and Challenges in Demand Response Pilots in Finland and Portugal, 15 InT. Conference on the Eur. EnERGY MARKET, June 2018, at 3.

${ }^{418} I d$.

${ }^{419} I d$.

${ }^{420} \mathrm{Id}$.

${ }^{421}$ EDP Distribuição, The S3C Consortium 2013, http://www.s3cproject.eu/News/30/EDPDistribuio.html (last viewed Mar. 26, 2020) [https://perma.cc/9RU7-T93C].

${ }^{422}$ Anthopoulos, Smart City Emergence: Cases from Around the World, 23-24 (2019).

${ }^{423} I d$. 
there are 3,500 facilities fitted with Demand-Side Management system. ${ }^{424}$ This DR model is consequential as it also monitors electric vehicle charging stations, distributed generation units, and primary distribution units in the assessment. ${ }^{425}$ This ensures consumers can organize demand-side management based on consumption, electricity generation, electricity rates, generation, responsive loads and distribution.426 This model has also promoted the use of electric vehicles and renewable energy. ${ }^{427}$

The regulatory constraints in Portugal have impeded the development of DR systems, and presently interruption contracts and capacity payments are the only legislated DR systems, which present limitations. However, the country is seeing the beginning of incorporation of pumped hydropower storage, and there are demonstration projects associated with DR systems that can incentivize discussions for the start of regulation in this area. ERSE should review the energy market in Portugal with the aim to open the market to DR, ancillary systems, and balancing markets.

\section{J. Electric Storage}

Portugal's renewable energy production is increasing, and it is estimated to reach a surplus in the range of 800-1200 GWh by $2020 .{ }^{428}$ As renewable energy becomes more and more relevant, it is crucial to develop efficient storage solutions that are economically viable to enable the use of such energy in periods of low demand. ${ }^{429}$ Storage potential of power-to-gas (PtG) technologies of at least 500GWh in Portugal has been estimated. ${ }^{430}$ There have been studies made to analyze the power-

$$
\begin{aligned}
& { }^{424} \mathrm{Id} \text {. } \\
& { }^{425} \mathrm{Id} \text {. } \\
& { }^{426} \mathrm{Id} \text {. } \\
& { }^{427} \mathrm{Id} \text {. } \\
& { }^{428} \text { Mateus \& Estanqueiro, Regulation of the wind power production: }
\end{aligned}
$$

Contribution of the electric vehicles and other energy storage systems, Proceedings of the 11th International Workshop on Large-Scale Integration of Wind Power into Power Systems as Well as on Transmission Networks for Offshore Power Plants, Lisboa, Portugal, 13-15 (2012) https://repositorio.lneg.pt/bitstream/10400.9/1885/1/Paper_WIW12052_CMateus.pdf [https://perma.cc/RLE4-JJ64].

${ }^{429}$ Zakeri \& Syri, Electrical energy storage systems: A comparative life cycle cost analysis, RENEW SustaIn ENERGy REV. 569-596 (2015).

${ }^{430}$ Heymann \& Bessa, Power-to-Gas potential assessment of Portugal under special consideration of LCOE, In Proceedings of the 2015 IEEE PowerTech Eindhoven, Eindhoven, The Netherlands, 1-5 (2015) 
to-gas storage potential in Portugal, such as the work by Heymann and Bessa estimated that the cost of PtG products in the country. ${ }^{431}$ Carneiro, et al., also foresaw the opportunity of extensive storage in geological formation in the mainland of Portugal. 432

In Portugal, there are different storage options, such as run-of-the-river and pumped hydro storage type hydropower plants. ${ }^{433}$ Pumped hydro storage plants collect substantial amounts of water that can be used in the months with the lowest levels of precipitation, while run-of-the-river mechanisms have small storage capacity, and the turbines that generate the electricity operate depending on the flow of the river. ${ }^{434}$ The pumped hydropower storage plants are the conventional method for the storage of electricity, which was modified to include a system for pumping water from a lower elevation to a higher elevation reservoir. ${ }^{435}$ Portugal has a capacity of $2.44 \mathrm{GW}$ of pumped hydro storage installed. 436

In 2015, global production of 1.16 terawatt-hour (TWh) through pumped hydro storage was reported by Redes Energéticas Nacionais (REN, Lisboa, Portugal). ${ }^{437}$ However, there is no further information on the values of power production by these means. ${ }^{438}$

According to the IEA, the daily renewable energy output by Portugal regularly exceeds the nation's energy demands and the excesses are used either in pumped hydropower storage plants or exported. ${ }^{439}$ The excess electricity consumed by pumped

https://repositorio.inesctec.pt/bitstream/123456789/3783/3/P-00K-2S2.pdf [https://perma.cc/XK76-BBM7].

${ }_{431} I d$.

${ }^{432}$ Carnerio, Matos, \& Gessel, Opportunities for large-scale energy storage in geological formations in mainland Portugal, RENEW SUSTAIN ENERGY REV. 201-209 (2019) https://dspace.uevora.pt/rdpc/bitstream/10174/25179/1/1-s2.0-S1364032118306786main.pdf [https://perma.cc/Q8UU-FAXA].

${ }_{433}$ Hydropower, Renewable Energy Technologies: Cost Analysis Series, Volume 1: Power Sector, Issue 3/5, International Renewable Energy AGency (June 2012), https://www.irena.org/documentdownloads/publications/re_technologies_cost_analysishydropower.pdf [https://perma.cc/4YN2-RS8D]

${ }^{434} I d$.

$435 \mathrm{Id}$.

${ }^{436}$ REN Thechnical Data, REN,

http://www.centrodeinformacao.ren.pt/PT/InformacaoTecnica/DadosTecnicos/REN\%20Dad os\%20T\%C3\%A9cnicos\%202016.pdf [https://perma.cc/LZ8G-6EER].

${ }_{437} \mathrm{Id}$.

${ }^{438} \mathrm{Id}$.

439 InT'L Energy Agency, Energy Policies of IEA Countries: Portugal, 16 (2016). 
hydropower storage plants almost tripled in 2015 compared to 2010 , with an efficiency of $78 \% .{ }^{440}$

Nevertheless, these plants require a substantial amount of investment and have been linked to detrimental environmental impacts that can foster divisiveness. ${ }^{441}$ To date, pumped hydropower storage plants have been the primary choice in the country to store any surpluses of renewable energy, but decentralized grids can increase the country's storage capacity and help the energy transition, as investment costs, geography, and environmental impacts can limit the extension of pumped hydro plants.

For this reason, there have been suggestions to use powerto-gas technologies, specifically power-to-methane. The renewable energy surpluses can be chemically stored as methane, inserted into the natural gas grid, or stored in reservoirs, such as in salt caverns, or even LNG tanks after being compressed. ${ }^{442}$ In Portugal, these power-to-methane (PtM) developments have the advantage of high capacity of wind power installations within the proximity of gas infrastructure, which makes the country very suitable for the implementation of PtM technologies, ${ }^{443}$ insofar as satisfactory carbon dioxide (CO2) sources are available in close proximity. ${ }^{44}$

Finally, the Sustainable Porto Santo/Smart Fossil Free Island project also focuses on finding storage solutions. ${ }^{445}$ The project aims to not only promote electric mobility but to create temporary storage through electric vehicles, as the surplus of renewable energy production is stored in V2G technology to meet the island's peak demands. ${ }^{446}$ Renault will install second-life electric vehicle batteries to create electric storage to enable the increase of renewable energy capacity on the island. ${ }^{447}$ As per the

\footnotetext{
${ }^{440}$ Heymann, supra note 430.

${ }^{441}$ Rehman, Al-Hadhrami, \& Alam, Pumped hydro energy storage system: A technological review, RENEW SUSTAIN ENERGY REV. 586-598 (2015).

${ }^{442}$ Miguel, supra note 169.

${ }^{443} \mathrm{Id}$. ("Almost $60 \%$ of that capacity located less than $5 \mathrm{~km}$ to existing or future potential natural gas storage facilities.").

${ }^{444}$ Heymann, supra note 430.

${ }_{445}$ See generally Deign, Renault Helps an Island Ditch Fossil Fuels With Vehicle to Grid Technology, GreEnTechMedia (Mar. 23, 2018)

https://www.greentechmedia.com/articles/read/renault-helps-an-island-ditch-fossil-fuelswith-v2g-technology\#gs.lycT1Kk [https://perma.cc/R6NL-NM4Y].

${ }^{446} I d$.

${ }^{447} \mathrm{Id}$.
} 
car company, the "world-first smart island uses electric vehicles, second-life batteries, smart charging, and V2G to boost the island's energy independence and stimulate the production of renewable energy (...)". ${ }^{448}$ This project may be the pilot needed to help progress V2G technologies in the sense that it will determine whether these are feasible and efficient in meeting the wanted results.

\section{K. Data Protection}

Recent technological developments such as the introduction of smart metering and smart grid systems may bring complications to further management and development of the energy sector by energy companies when considering the data protection rights of consumers. Smart grids and meters are essential for the future of the energy sector to effectively and efficiently manage energy use and supply, so companies can respond to local usage changes in response to gathered data. The EU Smart Grids Task Force recognizes the need for customers to accept the use of smart grids and requires Task Force control over energy consumption data. ${ }^{449}$

Consumers must feel assured that the new technology does not jeopardize the privacy of their personal data, and that such data is kept secure and their privacy respected. The Task Force established an expert regulatory group to make recommendations on smart grid privacy, cyber security, and data protection. ${ }^{450}$ Possible risks of handling data, security, and data protection were considered, including identifying ownership of data, access rights, and responsible parties. ${ }^{451}$ The Task Force provided a Commission Recommendation ${ }^{452}$ with ten minimum

${ }^{448}$ Groupe Renault and EEM to create first 'smart island' in Porto Santo, AutoMotiveWorLD (Feb. 21, 2018) https://www.automotiveworld.com/newsreleases/groupe-renault-eem-create-first-smart-island-porto-santo/ [https://perma.cc/T4EJEEBX].

449 Smart grids task force, EUROPA (Mar. 17, 2020)

https://ec.europa.eu/energy/en/topics/markets-and-consumers/smart-grids-andmeters/smart-grids-task-force [https://perma.cc/592G-NE5B].

${ }^{450} I d$.

${ }_{451} I d$.

${ }_{452}$ Best Available Techniques Reference Document for the cyber-security and privacy of the 10 minimum functional requirements of the Smart Metering Systems, EUROPA (Nov. 7, 2011) https://ec.europa.eu/energy/sites/ener/files/documents/bat_wp4_bref_smartmetering_systems_final_deliverable.pdf [https://perma.cc/34GE-MWNS]. 
functioning requirements, also included in the General Data Protection Regulation (GDPR) ${ }^{453}$ to ensure cyber security in smart metering systems. ${ }^{454}$ Article 23 of the GDPR expressly references smart meters, as the EU realized the data protection and security risks associated, as well as the technology's new potential. ${ }^{455}$ For continuing innovation and investment to go into smart meters, consumers must be confident not only in the network operation, but that consumer data will be protected against any breaches of privacy.

Portugal as a member state of the EU must ensure that it follows these principles. The regulatory framework in Portugal for the protection of private identifiable information (PII) stems from the direct application of the GDPR. ${ }^{456}$ The previous Portuguese Data Protection Act (DPA) was introduced in 1998 and revoked when the new DPA entered into force in 2019.457 Article 35 of the Portuguese Constitution governs PII principles and guarantees the right of an individual to access any computerized data about themselves in order to demand corrections, updates, and to be informed of the data's intended use. $^{458}$

The Portuguese government passed Law 58/2019 of August 8, 2019, which implemented legislation for the execution of the GDPR more than 15 months after the EU regulation became effective. ${ }^{459}$ The legislation applies to the processing of all personal data carried out in Portugal, notwithstanding the public or private nature of the controller or processor, and includes public interest tasks. ${ }^{460}$ This includes the energy sector, and even though it may be in the public interest to monitor data from

${ }^{453}$ EU Regulation 2016/679 of the European Parliament and of the Council of 27 April 2016, on the protection of natural persons with regard to processing of personal data and on the free movement of such data, https://eur-lex.europa.eu/eli/reg/2016/679/oj [https://perma.cc/97V7-5DSW].

${ }^{454}$ Commission Identification and Selection of the 10 Best Available Techniques for the 10 common minimum functional requirements related to the Smart Metering System, 4, COM (May 30, 2016).

${ }^{455}$ General Data Protection Regulation, Rights of the data subject:

Restrictions, ch. 3, art. 23.

${ }^{456}$ See generally Law on Protection of Personal Data (Law No. 67/98, art. 26)

(Port.).

${ }^{457} \mathrm{Id}$.

${ }^{458}$ Constituição da República Portuguesa [Port.] [Constitution] Apr. 25, 1976, 2, art. 35 (Port.).

${ }^{459}$ Data Protection Laws of the World, DLA Piper at 12 (Jan. 4, 2020).

${ }^{460} \mathrm{Id}$. 
smart meters to predict energy needs, the collector and processor must respect the consumer's data protection rights and have consent for the processing of the data, otherwise the collection and processing of the data will be a serious offence. ${ }^{461}$ Penalties can vary between $€ 5,000$ to $€ 20,000,000$ for a business, or $4 \%$ annual revenue, whichever is greater, and a maximum penalty of $€ 500,000$ for a natural person. ${ }^{462}$

Other serious offences that energy companies need to avoid include charging unreasonable fees to provide information under Article 12 of the GDPR and refusing to provide information collected on an individual. 463 Any data used for other reasons rather than the one it was collected for will have the perpetrator punished for up to a year imprisonment. ${ }^{464}$ The law further specifies that "anyone who, due to professional confidentiality legal obligations, without legal grounds and without proper consent, discloses in whole or in part personal data" can also face up to one year in prison, and double that for data protection officers or those seeking illegal personal gain. ${ }^{465}$

\section{Portugal's electricity interconnections within the EU}

The Synchronous grid of Continental Europe is the largest interconnection grid in the world, connecting electricity transmissions from 24 countries and suppling over 400 million customers, mostly in the EU. ${ }^{466}$ The TSO's operating the grid formed the Union for the Coordination of Transmission of Electricity (UCTE), now part of the European Network of Transmission System Operators of Electricity (ENTSO-E). ${ }^{467}$

\footnotetext{
${ }^{461} I d$.

${ }^{462}$ Id.; see also, Sérvulo, Last but not least, Portugal has finally implemented legislation for the execution of the GDPR, SERvUlo PUBILCATIONs (Aug. 13, 2019), https://www.servulo.com/xms/files/00_SITE_NOVO/01_CONHECIMENTO/01_PUBLICAC OES_SERVULO/2019/RGPD_Tabela_-_GDPR_Table.pdf/ [https://perma.cc/CF77-UXHQ] ${ }^{463} \mathrm{Id}$.

${ }^{464}$ General Regulation and Data Protection Law (Law No. 58/2019, art. 12)

(Port.).

${ }^{465}$ Law 58/2019 of Aug. 8, 2019, art. 46 (Port.).

466 Everything you need to know about the European Super Grid, OpUs ENERGY (July 28, 2017) https://www.opusenergy.com/blog/the-european-supergrid/\#: :text=A\%20super\%20grid\%20is\%20a\%20wide\%20electrical\%20network\%20which \%20crosses\%20national\%20borders.\&text=This\%20means\%20that\%20electrical\%20grids, network\%20powered\%20by\%20renewable\%20energy. [https://perma.cc/3SL2-RYE8].

467 See generally entsoe [https://perma.cc/TN94-6GHW] (last viewed Mar. 21, 2020) (summarizing the integration of the UTCE grid with the ENTSO-E).
} 
Increasing renewable energy capacity is one of the main pillars of progress within the EU, and Portugal has been performing brilliantly on that front. For example, in March 2018, APREN calculated that the average month's renewable output reached $103.6 \%$ from renewables. ${ }^{468}$ Additionally, NGO ZERO determined that the success from the renewable output resulted in 1.8 million tons less of $\mathrm{CO} 2$ emissions, contributing to a total savings of $€ 20$ million because there was no longer a need to buy ETS allowances. ${ }^{469}$ According to these sources, the wholesale price of electricity fell from $€ 43.94$ to $€ 39.75$ PER MWh. ${ }^{470}$

While the Portuguese and Spanish electricity markets are robust, Portugal's geographical location may create challenges, as its only connection to mainland Europe is the border with Spain. The EU's Energy Union plans to have an internal electricity market allowing surpluses of energy to be shared from a member state to another depending on demand. ${ }^{471}$ As storage solutions are still being developed, this plan is essential as the world moves more and more toward renewable energy sources.

As per EU standards, member states must reach a 10percent interconnection target by 2020, but both Portugal and Spain are behind that goal. ${ }^{472}$ The Iberian Peninsula has reached a 6-percent interconnection rate ${ }^{473}$ and continues to attempt overcoming being isolated from other member states by way of third-party interconnectors. ${ }^{474}$ Energy is already shared between Portugal and Spain, so much so that the surplus from renewable energy-generated electricity improved Portugal's exporting balance. ${ }^{475}$

468 Sam Morgan, Portugal breaks 100\% renewables mark but remains isolated, EURACTIV (Apr. 4, 2018) https://www.euractiv.com/section/energy/news/portugal-breaks100-renewables-mark-but-remains-isolated/ [https://perma.cc/U9HF-YWV2].

${ }^{469}$ European Commission Memorandum 18/4622, Integration of the Iberian Peninsula into the Internal Energy Market (July 27, 2018).

${ }_{470} I d$.

${ }^{471}$ See European Union, Energy Union strategy, Com 2015/080 (Feb. 25, 2015).

${ }^{472} I d$. at 2.

${ }^{473}$ European Commission Memorandum 18/4622, Integration of the Iberian Peninsula into the Internal Energy Market (July 27, 2018).

474 See European Commission Press Release IP/18/4621, European solidarity on Energy: Better Integration of the Iberian Peninsula into the EU Energy Market (July 27, 2018).

475 See id. 
Portugal and Spain trade electricity on a market known as the Iberian Market for Electricity (MIBEL). ${ }^{476}$ Within the MIBEL there are two organized markets: the spot market (day ahead and intraday), operated by the Spanish branch of MIBEL (OMIE) that abides by Spanish legislation, and the forwards and derivatives market, operated by the Portuguese branch of MIBEL (OMIP), which abides by Portuguese legislation. ${ }^{477}$ The OMIE works as a sole market for Portugal and Spain so long as the commercially available energy capacity between both countries is enough to satisfy the supply and demand of electricity orders. ${ }^{478}$

In the event enough capacity is insufficient, the two markets can be separated and specified prices for the separate markets are created under a market splitting mechanism. The generators in the special regime can sell their electricity to the supplier of last resort with feed-in-tariffs, which allows the supplier to then sell the electricity in the market by way of open auctions. Exports of electricity to Spain have totalled $€ 700$ million as of 2018 in under two years. ${ }^{479}$ In 2017, the country exported 5,753 GWh, worth €299 million, an increase from $€ 260$ million in $2016 .{ }^{480}$

Portugal, Spain, and France have agreed to better interconnection between the three countries, and have signed the Lisbon Declaration on energy interconnections. ${ }^{481}$ This reiterated support of projects between the Iberian countries, and the EU increased monetary support to $€ 865$ million for the construction of interconnections. ${ }^{482}$ Additionally, the Madrid Declaration, signed in 2015, will further help connect the Iberian Peninsula to the Internal Energy Market by removing obstacles to interconnection. ${ }^{483}$ These incentives will help the completion of ongoing projects and will drive increases in the rate of

\footnotetext{
476 See generally How does the MIBEL electricity market work?, ALEASOFT, https://aleasoft.com/how-mibel-electricity-market-work/ [https://perma.cc/5CTR-533J] (last viewed Mar. 21, 2020) (explaining the function of the transport grid operators in their respective roles).

477 See generally id.

478 See generally id.

${ }^{479}$ Pacheco and Mendes, supra note 172.

${ }_{480} \mathrm{Id}$.

481 See European Commission Lisbon Declaration, Second Energy Interconnections Summit Portugal-France-Spain, final (July 27, 2018).

${ }^{482}$ See Marian Willuhn, EU commits $€ 578$ million for Iberian-EU energy market integration, PV MAG (July 30, 2018) [https://perma.cc/XZ5U-8LBE].

${ }^{483}$ See generally Madrid Declaration (2015).
} 
interconnection in the region, which will make it possible to reach EU-designated targets.

\section{CONCLUSION AND RECOMMENDATIONS}

Latvia is progressing slowly, yet steadily, toward a smarter and more decentralized electricity system, following the direction of the EU's Clean Energy Package Regulations and Directives. The objectives presented in the Latvian National Energy and Climate Plan for 2021-2030 demonstrate the country's willingness to progress even further in all five dimensions of the European Energy Union.

While the EU member states' national plans have not yet taken their definitive form, as revised versions of the plans are due to be presented by the end of $2019,{ }^{484}$ and will be assessed in their final form in June 2020, ${ }^{485}$ the Latvian plan has been praised by the European Commission for its detailed estimations about its non-ETS targets and investment needs. ${ }^{486}$

As optimistic as this indication is, there are, however, certain aspects that could potentially be ameliorated to achieve the best results possible. For example, as data privacy and cybersecurity in energy infrastructure continue to affect the lives of millions of citizens, Latvian policy and legislation must develop quickly to counter those issues effectively. This will serve a dual purpose of protecting data and empowering consumers with confidence to move toward new technologies.

Regarding Portugal, this article has illustrated the current position of the Portuguese electricity market, especially decentralization efforts and inclusion of new technological advances in the energy sector. Notably, the country has a high energy dependence on imports of fossil fuels from countries such as Angola, even though it produces a high amount of energy from

${ }^{484}$ Communication from the Commission to the European Parliament, the European Council, the Council, the European Economic and Social Committee and the Committee of the Regions, The European Green Deal, at 6, COM (2019) 640 final (Nov. 12, 2019).

${ }^{485}$ Annex to the Communication from the Commission to the European Parliament, the European Council, the Council, the European Economic and Social Committee and the Committee of the Regions, The European Green Deal, at 2, COM (2019) 640 final (Nov. 12, 2019).

486 See Communication from the Commission to the European Parliament, the Council, the European Economic and Social Committee and the Committee of the Regions, United in delivering the Energy Union and Climate Action - Setting the foundations for a successful clean energy transition, COM (2019) 285 final (June 18, 2019). 
renewable sources and has steadily increased capacity in recent years. Portugal should take advantage of its strong geographical position and weather conditions to create more energy from renewable sources in order to liberate itself from fossil fuel imports.

Successfully decentralized energy grids are possible given Portugal's renewable capacity, allowing a steady decrease in imports and increase in renewable usage until the country is responsible for $100 \%$ of its own production and generation, a goal that Portugal already meets in more favourable months. The issues associated with increasing renewable capacity and the cessation of energy production with fossil fuels are the intermittent nature of renewable sources, and the need to store any surplus energy. To this end, there has been an increasing interest in lithium batteries. However, these are not seen as the most efficient option to store power.

There is a storage potential of $\mathrm{PtG}$ technologies of at least $500 \mathrm{GWh}$ and novel legislative incentives can attract investment in new storage facilities. If legislation is clear and precise on the importance and governmental stance of renewable energy sources, then investors will know the direction of the country in this respect and have more confidence in investing in new storage technologies. The government has shown vast support for renewable energy in the last decade, as can be seen by increases in capacity and various projects aimed to incentivize the use of renewables and alternative storage. Portugal uses environmentally unsafe hydropower pump storage for surplus renewable energy, so more research and development is needed for new technologies to emerge. Studies have identified that the development of storage from PtG, especially PtM, can be an efficient solution.

Additionally, Portugal's lithium availability can give the country an advantageous opportunity to develop the evolving battery-based technology market. Furthermore, using increasing amounts of renewable energy may in turn provide an effective solution for reducing greenhouse gas emissions not only from the energy sector, but also from the transport sector. In 2018, $61 \%$ of energy consumption needs were met by renewable energy, but electricity consumption in the transport sector, where fossil fuels dominate, only amounts to $0.8 \%$.

However, the country has seen many initiatives to promote the use of electric vehicles, and most importantly there has been a scale-up of charging infrastructure, instilling confidence in 
consumers that if they invest in an electric vehicle they know that the resources are there to make it convenient for them. Examples can be seen in the Electric Smart Grid project in Evora and the Sustainable Porto Santo/Smart Fossil Free Island project. These projects are of great significance as they are testing the feasibility of electric mobility and storage, using surplus energy produced by renewable sources and improved infrastructure to ease the transition. Portugal is moving in the right direction on electric mobility and storage and should continue to incentivize change in the transport sector in terms of infrastructure improvements, pilot programs, and subsidies where needed.

As these projects are having positive results in their objectives, more infrastructure should be introduced around the country to incentivize the use of electric vehicles, such as more charging points. If the infrastructure is there and electricity increasingly becomes more affordable, coming from renewable resources rather than by imported fossil fuels, it would make sense for the public to see the benefits and switch to this environmentally friendly technology, especially considering the financial assistance the Portuguese government provides on their acquisition and related tax exemptions. The experiences from these projects can help create parallel projects in the public transports sector, where not many pilot projects have incorporated electricity created by renewable energy. This not only would improve air quality and comply with GHG emission reduction targets imposed by the $\mathrm{EU}$ and other international treaties, but it would help reduce the high TFC and TPES that the transport sector uses.

Successfully decentralized electricity markets require a focus on clear responsibilities, strengthening of subnational capacities, and the coordination of disparate mechanisms. However, other conditions may be required, like territory-specific policies and allowing for asymmetric decarbonization - with differentiated responsibilities given to different regions or cities, and especially in metropolitan areas.

Adopting experimental policy practices can help the country adapt to decentralized systems more proactively, and multi-level governance reform tends to be less drastic than major reform of the electricity market directly. Government reform would be slower but would enable a "learn by doing" approach, better for flexible reforms of policies or provisions that do not achieve the objectives of needed. Portugal has seen a large scale 
up of renewable energy generation and policies to incentivize use, in addition to regional and private developments and partnerships that will drive rapid change in the country. For the transition toward renewable energy to happen as urgently as needed and as smooth as possible, regional systems must be coordinated and reorganized to benefit from decentralization.

Portugal is heading in the right direction in its decentralization efforts, however, in some areas it needs to make regulation more encouraging for the successful development and application of new technologies, while better enabling demand response programs and smart metering systems. In demand response programs, the only legislated area is that of interruptibility contracts, which suppliers are not very keen to use.

A few pilot programs taking place may signal a change in the emphasis the country is giving to this technology. Portugal and Spain are still below the interconnectivity target implemented by the EU. Some projects expected to resolve the interconnectivity issue are being financed by the EU. This may not be resolved in time for the 2020 deadline; nevertheless, it could meet the 2030 target of $15 \%$ interconnectivity. The country should focus on energy efficiency losses during transference to the shared grid to improve interconnectivity within the Iberian Peninsula.

As this article noted, there is no regulatory framework available in Portugal for the development of smart metering systems, which is why the government needs to introduce policies and incentives to accelerate the benefits this technology can have. The roll-out of smart meters, of global importance, started in 2009. Siemens is one of the suppliers of new smart meters to EDP Distribuição, which is installed in client's homes in a phased strategy. By 2020, $80 \%$ of customers' home-installed meters will be smart, initiating the replacement of analog meters. It is important to ensure that all homes will be equipped with the new technology, as most Portuguese households still use analog meters. The change of technology will be important in order to raise awareness in households on the density of energy used daily, which can also change attitudes toward energy use by the general public.

This may also influence energy generation, as customers choose to switch suppliers based on their personal usage of energy. A variety of service providers must be willing to provide services related to the vast introduction of this technology. 
However, it is unlikely that more players will join without clear regulatory and policy incentives by government and other public authorities.

Smart meters may also pose a privacy issue as suppliers and other entities collect personal data to keep records of energy supply and demand to help respond to need. Direct application of the GDPR can help protect consumers where data privacy is at stake in this circumstance and adding national regulation may create confusion and regulatory uncertainly. However, it should be noted that adding national stringency to this area may be beneficial as this technology is in its infancy, and the public should be further protected against any privacy breaches that may occur.

Demand response (DR) programs in Portugal are also in their infancy. However, a few pilot projects are currently being tested. DR is important for establishing peak demand trends, helping estimate the supply and demand needs of a country and making tariffs more dynamic. In Portugal, impeding deregulation constraints hinder the progress of DR systems, with only interruptibility contracts and capacity payments serving as legislative way to implement DR programs. Both of these options have limited participation and a surge of demonstration projects seems to be the way the country is trying to develop this technology. The DR sector can only really take off after a sufficient roll-out of smart metering systems in households and businesses, as DR policies work better with development and modernization of the supply sector.

Furthermore, demand response can be influenced by the introduction of obligations and responsibilities to interested parties. For example, responsiveness projects can be introduced to target large consumers and create patterns of supply and demand needed. As EDP is the main TSO in the country, there could be an introduction of a guideline by the TSO to the remaining TSO's in the autonomous regions, which could create legitimate enforcement measures to facilitate responsiveness.

Finding storage solutions is a global challenge at present, and the delays and costs to its development may significantly hinder low-carbon transition. Increasing renewable energy capacity and usage will only provide effective and efficient results if the surpluses of energy produced can be stored at low-demand times to be used at high-demand times. This is especially important in Portugal, as the daily renewable electricity output exceeds national demand, and the surpluses of such electricity 
are exported or stored in pumped hydropower plants. The storage sector provides for an opportunity for Portugal to develop a new market and possibly be an exporter of such technology on account of its large lithium reserves.

Presently, the storage options in the country consist of pumped hydropower storage from power stations and dams, which have thrived in the past few years. However, due to their environmental footprint and the amount of investment capital needed, hydropower may no longer be the most viable storage solution. There have been studies on the possibility of PtG implementation in electricity storage. Decentralized units would increase the country's storage capacity, and to this end PtG will be an effective solution, offering the possibility to integrate the electricity and increasingly utilized natural gas grids. Renewable energy would be stored chemically as methane, which could then be used at the storage site, injected into the natural gas grid, or stored in reservoirs such as LNG tanks (after compressed). This would benefit the wind capacity already installed in Portugal, as $60 \%$ of such infrastructure is located within a five-kilometer radius of existing or future gas infrastructure. 